\title{
Carbon disclosure, emission levels, and the cost of debt
}

Citation for published version (APA):

Kleimeier, S., \& Viehs, P. M. (2016). Carbon disclosure, emission levels, and the cost of debt. Maastricht University, Graduate School of Business and Economics. GSBE Research Memoranda No. 003 https://doi.org/10.26481/umagsb.2016003

Document status and date:

Published: 01/01/2016

DOI:

10.26481/umagsb.2016003

Document Version:

Publisher's PDF, also known as Version of record

\section{Please check the document version of this publication:}

- A submitted manuscript is the version of the article upon submission and before peer-review. There can be important differences between the submitted version and the official published version of record.

People interested in the research are advised to contact the author for the final version of the publication, or visit the DOI to the publisher's website.

- The final author version and the galley proof are versions of the publication after peer review.

- The final published version features the final layout of the paper including the volume, issue and page numbers.

Link to publication

\footnotetext{
General rights rights.

- You may freely distribute the URL identifying the publication in the public portal. please follow below link for the End User Agreement:

www.umlib.nl/taverne-license

Take down policy

If you believe that this document breaches copyright please contact us at:

repository@maastrichtuniversity.nl

providing details and we will investigate your claim.
}

Copyright and moral rights for the publications made accessible in the public portal are retained by the authors and/or other copyright owners and it is a condition of accessing publications that users recognise and abide by the legal requirements associated with these

- Users may download and print one copy of any publication from the public portal for the purpose of private study or research.

- You may not further distribute the material or use it for any profit-making activity or commercial gain

If the publication is distributed under the terms of Article $25 \mathrm{fa}$ of the Dutch Copyright Act, indicated by the "Taverne" license above, 


\section{Maastricht University}

Stefanie Kleimeier, Michael Viehs

Carbon Disclosure, Emission Levels, and the Cost of Debt

RM/16/003

\section{GSBE}

Maastricht University School of Business and Economics

Graduate School of Business and Economics

P.O Box 616

NL- 6200 MD Maastricht

The Netherlands 


\title{
Carbon Disclosure, Emission Levels, and the Cost of Debt"
}

\author{
Stefanie Kleimeier \\ Maastricht University - School of Business and Economics \\ University of Stellenbosch Business School \\ Open Universiteit \\ The European Centre for Corporate Engagement (ECCE)
}

\author{
Michael Viehs
}

Hermes Investment Management - Equity Ownership Services

University of Oxford - Smith School of Enterprise and the Environment

The European Centre for Corporate Engagement (ECCE)

This version: 15 January 2016

\begin{abstract}
In this paper, we investigate the effect of voluntary carbon emissions disclosure on the cost of debt of publicly listed firms. Using a unique and comprehensive database on carbon emissions from CDP (formerly 'The Carbon Disclosure Project'), we study whether firms which choose to voluntarily disclose their carbon emissions enjoy more favorable lending conditions - in the form of lower spreads on their bank loans - than their non-disclosing counterparts. Our empirical results reveal a significant and negative relation between voluntarily disclosing carbon emission levels and the cost of bank loans for informationally opaque borrowers. Furthermore, we find that higher industry- and firm-size-adjusted carbon emissions have a positive and significant effect on loan spreads. These effects are common to all loans and not limited to loans which have been arranged by norms-constrained lenders suggesting that spread premia are driven by environmental risks rather than investor preferences.
\end{abstract}

Keywords: Carbon disclosure, carbon emissions, cost of debt, loan spreads.

JEL classification: A13, G21, Q51

\footnotetext{
* We a grateful to CDP for generously sharing their data with us. In particular, we thank Leyla Basacik, Patrick Crawford, James Hulse, and Emma Wheelan from CDP for their invaluable support during the data management process. We thank Elaine Craig, Inga Minakova, and Wei Xi for their valuable research assistance. We are also grateful to Nadja Guenster, and seminar participants at the University of Muenster, University of Stellenbosch Business School, and the UNPRI for their helpful comments and feedback on the paper. We also received valuable feedback from conference participants at the INFINTI conference 2015 in Ljubljana and the European Responsible Investing Conference in Hamburg. The email addresses of the authors are: s.kleimeier@maastrichtuniversity.nl and michael.viehs@smithschool.ox.ac.uk. The views expressed in this paper are solely the views of the authors and do not necessarily represent the views of Hermes Investment Management or Hermes Equity Ownership Services.
} 


\section{Introduction}

One of the leading questions in the environmental economics and financial economics literatures over the last decade has been whether capital markets pick up and price extrafinancial information on environmental, social, and governance issues (ESG), which provides information on potential investee companies that go above and beyond the standard financial information such as accounting information of balance sheets and income statements. Usually, this extra-financial information is considered to be a three-dimensional framework, which comprises information about the environmental (E), social (S), and governance (G) performance of companies that investors can invest in.

Up till now, there is a plethora of literature investigating the different facets of ESG and their influence on the financial performance of companies, their operational performance, or their cost of capital. In this paper, we focus on the environmental dimension of the ESG universe. More precisely, we study whether the conscious decision taken by companies to voluntarily disclose their carbon emissions and the level thereof are related to the company's interest costs (i.e., loan spreads) that these companies have to pay on their bank loans. Stated differently, we research the relation between the carbon emissions and the company's cost of debt. To do so, our analysis is split into two distinct parts. First, we investigate the effect of voluntarily disclosing carbon emissions and the loan spread a company has to pay. Second, we examine the effect of the actually revealed emissions levels on a company's loan spread.

The results of our empirical analyses can be summarized as follows. We find that informational opaque firms which choose to voluntarily reveal their carbon emissions pay significantly lower spreads on their bank loans, as compared to their non-disclosing counterparts. Regarding the absolute emission levels, we find that firms with relatively more carbon emissions pay higher spreads on their loans. Both effects exist for all bank loans and are not driven by the fact whether so-called norms-constrained lenders are among the lead arrangers for the bank loans. Hence, our results imply that firms should be aware that 
voluntary emissions disclosure and the corresponding emission levels affect their cost of debt. Similarly, our results also have implications for firms that have relatively higher emission levels or firms that have little managerial control over their emissions and therefore might have to pay higher cost of debt: according to our results, carbon emissions could be considered as an additional risk factor that banks take into account (i.e., either directly or indirectly), when assessing the creditworthiness of a borrower.

The timeliness and importance of our study is not to be understated, especially against the backdrop of the ongoing debates about climate change and pollution, and the recently signed Paris Agreement of the COP21. Countries pledged to undertake actions in order to limit the global warming to a maximum of 1.5 degrees Celsius. These actions will also influence companies and their operations, be it through the immediate introduction of new environmental regulations to limit carbon emissions, or through the introduction of an explicit carbon price which would impose a huge cost fact on companies. Ultimately, these actions impose additional risks on companies, especially on those companies operating in environmental sensitive industries such as fossil fuel, mining, or oil and gas industries.

Alongside these recent political and legislative developments, there also is an ongoing academic discussion regarding the influence of ESG information on companies and corresponding investment decisions by the financial industry. Nowadays, there is convincing evidence that companies with better ESG practices do not perform worse than companies with bad ESG practices. Rather the contrary has been documented in the existing literature: Good ESG practices can lead to better financial performance and lower cost of capital for companies (see, for example, Friede, Busch, and Bassen, 2015 and Clark, Feiner, and Viehs, 2015). There is also evidence that the environmental performance of companies has a direct effect on a company's cost of equity and cost debt (see, for example, Chava, 2014).

Despite this growing evidence, we add significantly to various streams of the existing literature and also provide financial market participants with new and important implications 
and recommendations. First, we add to the voluntary disclosure literature by investigating the effect of increasing transparency from corporations with respect to their environmental performance. We argue that by voluntarily disclosing their carbon emissions, companies can reduce information asymmetries and uncertainties vis-à-vis their capital providers and thus reduce their cost of capital. This argument is based on the theoretical arguments put forward in Diamond and Verrecchia (1991) as well as Lambert, Leuz, and Verrecchia (2007).

Second, we add to the responsible investment literature that documents the influence of norms-constrained investors on the cost of capital of corporations. On the one hand, institutional investors with certain norms and moral beliefs might eschew potential investee firms because of the industry they are operating in (particularly the so-called "sin" industries such as tobacco, alcohol, or military defense). On the other hand, norms-unconstrained institutional investors could remain keen to invest in such firms but may demand a higher price or return for the capital provided. In this study, we investigate whether normsconstrained lenders have an effect on a firm's cost of debt by charging a risk premium in case of poor environmental performance (i.e., higher carbon emission levels), assuming the lenders are being especially interested in the environmental performance of their borroerws. This reasoning is similar to the arguments in Hong and Kacperczyk (2009), Heinkel, Kraus, and Zechner (2001), and Gollier and Pouget (2012).

Third, we also add to the investment literature which documents that firms with better ESG practices generally have a significantly lower cost of capital because they are better prepared for adverse effects that could arise from severe environmental, social, or governance events (which might change the risk profile of a firm). Thus, firms with, for example, better environmental safety standards or better environmental management practices have lower costs of capital. Sharfman and Fernando (2008), Chava (2014), and Goss and Roberts (2011) show that corporations with good ESG practices tend to have significantly lower costs of debt capital. We investigate if banks price the risks inherent in poor environmental performance 
such as litigation or reputation risks as part of the firm's credit risk. If that reasoning is correct, lenders will charge higher interest rates for borrowers which display a relatively worse environmental performance.

We add to these streams of literature by investigating the effect of carbon disclosure and actual carbon emission levels on a corporation's cost of debt financing. We concentrate on the corporation's cost of bank debt and are able identify different investor types, i.e. lenders who are environmentally norms-constrained and those who are not. This allows us to differentiate two types of cost of debt effects: effects of carbon disclosure that are present for all lenders and thus suggest the presence of an environmental risk premium; versus effects of carbon disclosure that are only present for norms-constrained lenders and thus suggest the presence of investor preferences.

Our study is unique in a number of ways. First, we extend the literature by measuring the impacts of voluntarily reporting carbon emissions and carbon emission levels on firm's cost of capital. That is, we take a direct environmental performance measure (i.e., the absolute carbon emission level reported) rather than an indirect measure (e.g., an environmental rating) which is usually taken in existing studies to proxy for the environmental performance of a company. Second, we use a global sample of firms. More specifically, we look at companies that are domiciling in 58 different countries. This global approach makes our study very distinctive from existing ones, which usually focus on the US market. Finally and as mentioned before, we are able to clearly differentiate whether investor preferences or environmental risks drive the differences in loan spreads.

The remainder of this paper is organized as follows. In section 2, we present our research hypotheses in relation to the existing literature. This is followed by section 3 , where we explain and describe the data sources and present our empirical method that we adopt in this paper. Then, in section 4, we present our main empirical findings and the results from our robustness check. Finally, we conclude in section 5. 


\section{Related literature and research hypotheses}

The main research question of our paper is: "What are the effects of voluntary carbon emissions disclosure and actual carbon emission levels on the loan spreads that companies have to pay on their outstanding bank loans?". We answer this research question using three main hypotheses which we derive now from the existing literature.

The corporate finance and accounting literatures both show that better information disclosure by corporations generally results in a lower cost of capital because of reduced information asymmetries and uncertainties (e.g., Diamond and Verrecchia, 1991 and Lambert, Leuz, and Verrecchia, 2007). These findings have been supported and even reinforced by review studies such as Armstrong, Guay, and Weber (2010) and Beyer, Cohen, Lys, and Walther (2010). The general evidence on the effects of voluntary disclosure on companies points to the conclusion that disclosing information to financial markets reduces a company's informational opaqueness. Voluntarily revealing material information to market participants can have three major effects on companies and their issued securities. First, it can reduce information asymmetries between firms and capital providers. Second, firms can use voluntary disclosure of relevant information (and the resulting lower information uncertainty) to increase investor demand for their securities. And third, firms can increase the market liquidity of their securities by disclosing more information. Ultimately, these arguments imply that more disclosure by corporations leads to a reduced cost of capital. Thus, we argue that those firms which voluntarily opt for reporting and revealing their carbon emissions have a reduced cost of debt capital, because lenders value the higher transparency of corporations irrespective of whether norms-constrained lenders are amongst the lead arrangers in the loan syndicate. Hence, we posit our Voluntary Disclosure Hypothesis (VDH) as:

VDH: $\mathrm{CO}_{2}$ emissions disclosure is negatively associated with corporations' costs of debt.

We also focus in this paper on the relationship between actual corporate environmental performance (measured through actual carbon emission levels) and the costs of 
bank debt. The general argument in the literature is that superior ESG practices help reduce the risk for companies that arise from potential externalities. For example, Godfrey, Merrill, and Hansen (2009) argue that superior CSR activities act as an insurance against adverse ESG events if these activities are designed to serve secondary stakeholders and society in general. That is, if corporations implement reasonable ESG policies, they might not be as severely affected by environmental disasters, or newly introduced regulations regarding climate change, as corporations which have relatively weaker ESG standards in place. Similar arguments have been put forward by Chava (2014) as well as Bauer and Hann (2010), who also stress the lower reputational and litigation risk that superior ESG standards carry with them. Both studies show that companies with better environmental management systems in place and hence, better environmental ratings, do have to pay significantly lower costs on their bank loans and have better credit ratings. This in turn implies that more sustainable companies, in terms of environmental performance (i.e., in our paper context these are companies with relatively lower carbon emission levels), have lower credit risk than their less sustainable peers because of, for example, a reduced volatility of future earnings or an improved competitive position of firms vis-à-vis less sustainable counterparts. In the context of our paper, this implies that lenders might take the environmental performance of borrowers into account when assessing the creditworthiness of firms. Consequently, firms with a poor environmental performance should pay higher interest rates on their bank loans. This argument is tested using the Risk Mitigation Hypothesis (RMH):

RMH: The actual amount of industry-and firm size-adjusted $\mathrm{CO}_{2}$ emissions by the borrower is positively associated with the cost of debt.

If we were to find evidence in favor of the risk-mitigation hypothesis $(\mathrm{RMH})$, our results should hold true for all borrowers - irrespective of whether norms-constrained lenders are involved in the loan syndicate or not. However, it could then also be the case that a potential positive association of carbon emissions and the cost of debt is driven by those loans 
that have been initiated by norms-constrained lenders which pay particular attention towards the carbon emission levels of their borrowers. In the spirit of Heinkel, Kraus, and Zechner (2001), Hong and Kacperczyk (2009) and Gollier and Pouget (2012), we therefore hypothesize that environmentally norms-constrained investors are especially concerned about the environmental performance of the firms they lend to or invest in. To assess whether norms-constrained lenders take carbon emissions into consideration when they price loans to corporations, we test our third research hypothesis, the Investor Preference Hypothesis (IPH): IPH: The rise in the cost of bank debt is driven by those loans which have norms-constrained lenders among the loan's lead arrangers.

Using the three aforementioned research hypotheses, we are going to answer the main research question of our paper and provide the literature and the financial services industry with unique evidence on the association of carbon disclosure and carbon emission levels with a company's cost of bank capital.

\section{Data}

\subsection{Data sources}

The data for our analyses come from two main sources: CDP (formerly known as the 'Carbon Disclosure Project') and DealScan. We use CDP to (1) obtain firm-specific data on environmental disclosure and carbon emissions and (2) classify those institutional investors who are signatories to $\mathrm{CDP}$ as environmentally norms-constrained investors. We use DealScan to collect information about corporate loans including loan spreads and the identity of the loan's lead arrangers. By matching lead arrangers to CDP's signatories, we are able to identify those loans that are arranged by norms-constrained arrangers. Hence, our dataset is different to existing ones and provides us with the unique opportunity to directly observe the presence of norms-constrained investors on the loan level and match it to the environmental performance of a specific borrower. 
$\mathrm{CDP}$ is a UK-based not-for-profit organization that aims to "use the power of measurement and information disclosure to improve the management of environmental risk" (CDP, 2015a). To achieve this goal, CDP targets companies with an annual survey concerning their carbon emissions, investments into climate change and environmental management techniques. Between 2002 and 2013, CDP's outreach has increased from the UK's FTSE500 firms to about 1,200 firms worldwide. While CDP typically sends the questionnaire to those firms which have publically traded equity, the companies are typically constituents of the major stock market indices such as FTSE Global Equity Index Series - All Cap, FTSE AllWorld Developed - Large Cap, S\&P/IFCI Large/Mid Emerging Market Index, as well as specific industrial sectors such as electricity, fossil fuels, and transportation. ${ }^{2}$

For all companies that are targeted by CDP, we categorize their responses to the annual questionnaire into one of three groups: (1) disclosure (the targeted firm answers the questionnaire); (2) no response (CDP does not receive any response from the targeted firm); and (3) declined to participate (the targeted firm informs CDP that it does not wish to complete the questionnaire). ${ }^{3}$ In the context of our Voluntary Disclosure Hypothesis, we consider only firms belonging to the first group to be those firms who voluntarily disclose environmental information. The firm's annual carbon emissions are part of the information contained in the questionnaire responses and we use this information to test our Risk Mitigation and Investor Preference Hypotheses.

In 2015, CDP is backed by more than 822 signatories, including institutional investors with a combined asset base of more than US\$ 95 trillion. As signatories, these investors have access to all information provided by targeted corporations in the responses to CDP annual questionnaire. ${ }^{4}$ In return, the signatories support CDP "through endorsement of our annual questionnaires" to their investee firms (CDP, 2015b). We assume that those financial

\footnotetext{
2 A full list of firms participating in the 2014 Climate Change Program can be found here: https://www.cdp.net/Documents/Guidance/2014/companies-requested-to-respond-cdp-climate-change-2014.pdf ${ }^{3}$ In the empirical analyses of this paper, we treat the category "decline" as the base case.

${ }^{4}$ For a full list of CDP signatories see https://www.cdp.net/en-US/Programmes/Pages/Sig-Investor-List.aspx.
} 
institutions which become CDP signatories are especially concerned about the environmental performance of the firms they lend to or invest in. Therefore, we consider lenders who are signatories to CDP to be norms-constrained arrangers with respect to the environment, as in the spirit of Heinkel, Kraus, and Zechner (2001) and Hong and Kacperczyk (2009). Identifying signatories among the borrower's debtholders thus allows us to test our Investor Preference Hypothesis.

Our second main data source is Thomson Reuters' LPC DealScan database. DealScan contains information about bilateral and syndicated loans signed since 1987 by private and public borrowers worldwide. Of particular interest for our study is each loan's spread and syndicate structure. The former constitutes our measure of the firm's cost of debt. The latter allows us to identify CDP signatories among each loan's lead arrangers. The DealScan database also contains information on loan characteristics such as: signing date; size; maturity; pricing details (including base rate and performance pricing); financial covenants; tranching; purpose; type; and security or seniority. Furthermore, the borrower's industry, country and credit rating are included.

To analyze the effect of carbon emissions disclosure on the cost of bank loans for corporations, we merge the entire CDP database from 2007-2013 with Thomson Reuters' LPC DealScan database. In particular, we match firms targeted by CDP and CDP signatories with DealScan's borrowers and lead arrangers, respectively. As CDP exclusively targets firms which have publicly traded securities outstanding, we include loans to all such public borrowers. Our sample therefore includes not only loans to borrowers who actually received a questionnaire from CDP but also loans to borrowers that could potentially have received a questionnaire. We identify public borrowers by the fact that they have a corporate identifier (GVK) available in Compustat North America or Compustat Global or an ISIN in Worldscope. We only consider borrowers from countries in which CDP targeted at least one borrower between 2007 and 2013. Consequently, our sample consists of loans to firms 
targeted by CDP and control firms. In this way, we are able to control for any potential selection effects in case that firms targeted by CDP differ from the general population of public corporate borrowers. Due to the more comprehensive coverage of non-US firms in Worldscope, we collect financial statement data for all borrowers from Worldscope including the borrower's total assets, ROA, and leverage.

\subsection{Methodology}

To test our Voluntary Disclosure Hypothesis, we adopt a standard ordinary least squares framework where we regress the natural logarithm of the loan spread in basis points (bps) on a set of explanatory variables as shown in regression 1:

$$
\begin{gathered}
\ln (\text { loan spread })=a_{0}+a_{1} C D P \text { target } \\
+a_{2} \text { Response to CDP questionnaire }+a_{3} X+\varepsilon
\end{gathered}
$$

CDP target equals one if CDP targeted the borrower with a questionnaire and zero otherwise. ${ }^{5}$ Response to CDP questionnaire is a vector of dummy variables reflecting the borrower's response to the questionnaire including Disclosure, No response, and Decline. $\mathrm{X}$ is a vector of control variables related to loan, borrower, country and time characteristics. In various specifications of our empirical model, this vector also controls for the fact whether normsconstrained arrangers (NCA) are participating in the loan syndicate. Loan-level controls include loan size and maturity, dummies for the presence of performance pricing, financial covenants, multiple base rates and deals consisting of multiple tranches as well as groups of dummy variables for each loan purpose, type, security, and seniority level. Borrower controls include dummies for borrower credit rating, industry, and country. Finally, we include time dummies reflecting the year of loan signing. ${ }^{6}$ For the Voluntary Disclosure Hypothesis, the coefficients of interest are included in $\mathrm{a}_{2}$. The null hypothesis is that $\mathrm{a}_{2}$ equals zero. In

\footnotetext{
${ }^{5}$ CDP sends out its annual questionnaire in February and firms typically reply by June. Thus, their answers refer to the situation in the previous year, i.e., $\mathrm{t}-1$. We therefore match questionnaires sent out in year $\mathrm{t}$ with loans signed in year t. We treat CDP signatory status in the same way.

${ }^{6}$ See Table A1 in the Appendix for a detailed description of all variables.
} 
contrast, we expect a negative coefficient for loans to disclosing borrowers. As mentioned before, in some specifications, we add a Norms constrained arranger (NCA) dummy and an interaction effect with the company's response to the questionnaire, in order to investigate whether any spread effect is common to all banks or limited to norms-constrained banks. $N C A$ equals one if at least one of the loan's lead arrangers is a CDP signatory and zero otherwise. ${ }^{7}$ The regression sample for which these proxies are available consists of 17,643 loans signed between 2007 and 2013. As borrowers can be included in the sample with multiple loans, standard errors are heteroskedasticity-robust and clustered on the borrower level.

As shown in regression (2), we apply a similar regression framework to test our Risk Mitigation and Investor Preference Hypotheses:

$$
\begin{gathered}
\ln (\text { loan spread })=b_{0}+b_{1} C_{2}+b_{2} N C A+b_{3} C O_{2} * N C A \\
+b_{4} X+\varepsilon
\end{gathered}
$$

$\mathrm{CO}_{2}$ measures industry- and firm-size-adjusted carbon emissions, arising either in form of Scope 1 or Scope 2 type of emissions. $N C A$ and our vector of control variables $X$ are defined as in regression (1). The differentiation between Scope 1 and Scope 2 emission levels has been introduced by the Greenhouse Gas Protocol and has become a widely recognized standard for the measurement of $\mathrm{CO}_{2}$ emissions. ${ }^{8}$ For the Risk Mitigation and Investor

\footnotetext{
${ }^{7}$ In some of the empirical specifications in which we analyse the effect of the actual amounts of carbon emissions on the loan spread, we define NCA differently. In Table 3, we define NCA in some specifications as the fraction of CDP signatories among the loan's arrangers.

${ }^{8}$ The Greenhouse Gas Protocol (GHG Protocol) specifies the use of so-called Scope 1 and Scope 2 emissions. According to GHG Protocol, Scope 1 emissions are all direct GHG emissions: "Direct GHG emissions occur from sources that are owned or controlled by the company, for example, emissions from combustion in owned or controlled boilers, furnaces, vehicles, etc.; emissions from chemical production in owned or controlled process equipment". On the other hand, Scope 2 emissions are all Electricity indirect GHG emissions: "Scope 2 accounts for GHG emissions from the generation of purchased electricity consumed by the company. Purchased electricity is defined as electricity that is purchased or otherwise brought into the organizational boundary of the company. Scope 2 emissions physically occur at the facility where electricity is generated". We stick to GHG because this is also the standard applied by CDP: "The Greenhouse Gas Protocol (GHG Protocol) is the most widely used international accounting tool for government and business leaders to understand, quantify, and manage greenhouse gas emissions. The GHG Protocol, a decade-long partnership between the World Resources Institute and the World Business Council for Sustainable Development, is working with businesses, governments, and environmental groups around the world to build a new generation of credible and effective programs for tackling climate change" (GHG Protocol, 2014).
} 
Preference Hypotheses, the coefficients of interest are $\mathrm{b}_{1}$ and $\mathrm{b}_{3}$. For the Risk Mitigation Hypothesis, the null hypothesis is that $\mathrm{b}_{1}$ and $\mathrm{b}_{3}$ equal zero while we expect a positive coefficient for $b_{1}$ in combination with a zero coefficient for $b_{3}$ indicating that loans to borrowers with higher carbon emissions are priced at a higher spread by all lenders. For the Investor Preference Hypothesis, the null hypothesis is that $\mathrm{b}_{1}$ and $\mathrm{b}_{3}$ equal zero while we expect a zero coefficient for $b_{1}$ in combination with a positive coefficient for $b_{3}$ indicating that loans to borrowers with higher carbon emissions are priced at a higher spread only by normsconstrained lenders. The regression sample for which these proxies are available consists of 1,600 loans signed between 2007 and 2013. In contrast to the sample for regression (1), we are now focusing only on loans to borrowers that are targeted by CDP with a questionnaire and disclose carbon emission levels. ${ }^{9}$

\subsection{Unconditional loan spreads}

Figure 1 presents the unconditional spreads for our sample of 17,643 loans. The average spread for all public borrowers is 238 bps. However, differentiating between those publicly listed firms which received the CDP questionnaire to disclose their carbon emissions and those publicly listed firms which were not invited by CDP to participate, reveals the first evidence in favor of our Voluntary Disclosure Hypothesis: companies that receive the questionnaire have to pay a substantial lower spread (176 bps) than the firms which do not receive it (262 bps). One explanation for this finding could be that CDP is targeting the supposedly larger, more mature firms which have to pay lower spreads because of their specific corporate performance and firm characteristics which are not necessarily related with the carbon disclosure question. Hence, this finding strongly indicates the need to control for firm characteristics. Finally, Figure 1 illustrates the average spreads depending on the firm's response to the CDP questionnaire. Borrowers that answered the questionnaire, i.e. borrowers who disclose, pay the lowest loan spread of 164 bps amongst the three different response

\footnotetext{
${ }^{9}$ Table A2 in the Appendix provides descriptive statistics for both regression samples.
} 
groups. Companies that do not respond pay a higher loan spreads, namely $197 \mathrm{bps}$. The highest loan spreads, however, pay firms that actively declined to participate in the CDP survey. These borrowers have to pay on average a spread of $203 \mathrm{bps}$.

\section{***** Insert Figure 1 about here ****}

These unconditional descriptive statistics for the loan spreads allude to the fact that less environmentally transparent firms have to pay substantially higher loan spreads, whereas more environmentally transparent firms enjoy more favorable lending conditions. However, we have to be careful with making any causal inferences from these unconditional results as it could be well the case that our sample is suffering from a sample selection bias, namely that only the largest and best performing firms regarding carbon emissions are targeted by CDP which might affect the observed loan spreads.

\section{$4 \quad$ Results}

\subsection{Evidence on the Voluntary Disclosure Hypothesis}

Table 1 presents the baseline results for our Voluntary Disclosure Hypothesis. The negative and significant coefficient of our CDP target proxy in Model 1 reveals that borrowers targeted by CDP with a questionnaire pay significantly lower spreads on their bank loans than non-targeted borrowers. In itself, this result indicates that even after controlling for borrower, loan, country and time characteristics, firms targeted by CDP are still substantially different from other borrowers due to some unobserved characteristics. However, the results of Model 2 refute this interpretation. In this model, we add our binary variables indicating the borrower's response to the questionnaire. As mentioned before, we differentiate between three different response alternatives: disclosure, no response, and declining to participate, whereas the latter category is the base case in all of our analyses. We find a nonsignificant coefficient for CDP targets but a negative and significant coefficient for disclosing borrowers. This indicates that the negative effect of receiving the questionnaire documented in Model 1 is fully explained by firms that answer the questionnaire. Hence, we can conclude that it is not a 
question of receiving the questionnaire (i.e., the selection of target firms by CDP) that negatively influences the loan spread. Instead, it is the actual act of answering CDP's questionnaire that matters: the full disclosure coefficient confirms our Voluntary Disclosure Hypothesis and our results are statistically as well as economically significant.

The economic size of this observed statistical relationship is also worth being pointed out. The interpretation goes as follows. The average loan size in the underlying sample of Model 2 is US\$ 497 million and the average spread margin across all loans in the sample is 238 bps. Hence, the spread for an average firm amounts to US\$ 11.8 million (US\$ 497 million $\mathrm{x} 2.38 \%$ ) per annum. The coefficient of -0.11 on the full disclosure variable implies that the percentage difference in the loan spread between firms that disclose environmental information and those that do not equals $\left.-10 \%\left[=100 \times\left(\exp ^{-0.11}\right)-1\right)\right]$. Hence, all else equal, the economic interpretation of this result implies that disclosing firms save, on average, interest costs to the amount of US\$1.2 million per annum. Thus, our empirical results are not only statistical meaningful, they also carry huge economic implications with them. Moreover, the coefficients of the remaining control variables are in line with the empirical loan pricing literature which strengthens the robustness of our results even further.

**** Insert Table 1 about here $* * * *$

As the disclosure coefficient in Model 2 is significant only at the $10 \%$ level, we provide additional evidence regarding the Voluntary Disclosure Hypothesis in Models 3 to 5 of Table 1. To begin with, we consider different levels of information asymmetry between borrower and lender in Model 3 of Table 1 because it has been shown that the level of information asymmetry is an important determinant of loan spreads and credit risk (see, for example, Diamond and Verrecchia, 1991). That is, we investigate whether disclosing environmental information through CDP has the potential to reduce the informational opaqueness that several companies are suffering from because they are assessed as being relatively nontransparent with respect to investor-relevant information. To test this, we identify opaque 
borrowers as borrowers that lack a credit rating or financial statement information and interact this information with the binary variable which identifies the disclosure of relevant carbon information through CDP. The significant and negative interaction term of -0.12 in Model 3 indicates that increased transparency in form of environmental disclosure is associated with lower spreads for opaque borrowers. In contrast, the coefficient of the standalone disclosure variable is now insignificant indicating that transparent borrowers do not benefit from environmental disclosure. Thus, our Voluntary Disclosure Hypothesis applies only to opaque borrowers with an economic relevance similar to the one reported for Model 2.

Next, we consider the relevance of norms-constrained investors. As our Voluntary Disclosure Hypothesis is motivated on the basis on information asymmetry and uncertainty, we do not expect NCAs to behave differently from unconstrained arrangers. Instead, we expect both groups to price information uncertainty with a similar economic and statistical magnitude. The results of Model 4 confirm our expectation as the coefficients of our NCA dummy and its interaction term are both insignificant. Finally, we replicate our main results of Model 3 for the sub-sample of borrowers targeted by CDP with a questionnaire. The results of this analysis are presented in Model 5 and are consistent with our previously documented results.

In sum, the results presented in Table 1 support our Voluntary Disclosure Hypothesis and indicate that voluntary disclosure of environmental information is economically valuable to borrowers with a high level of information uncertainty in the form of interest cost savings of up to $\$ 1.2$ million annually.

\subsection{Evidence on the Risk Mitigation and Investor Preference Hypotheses}

We now turn to the question whether the absolute carbon emission levels are influencing the loan spreads, at least for those companies that opt to report their carbon performance through CDP. Starting with some unconditional findings about the level of carbon emissions, Figure 2 shows the mean and median emissions by industry. These 
statistics are entirely based on all firms with full disclosure. ${ }^{10}$ Not surprisingly, both Scope 1 and Scope 2 emissions vary greatly by industry. The highest Scope 1 carbon emissions, e.g. the direct emissions generated by the firm, can be found in primary metals manufacturing, petroleum refining and transportation sectors. Levels of Scope 2 carbon emissions, e.g. indirect emissions from electricity purchase in the supply chain, are substantially smaller but also vary greatly across industry - the highest emissions being found in the primary metals manufacturing and trade sectors.

These industry variations have clear implications for our measurement of firm-level emissions. In the analyses that follow, we adjust the reported carbon emissions in the following manner. First, we scale the level of carbon emissions in metric tons by the firm's amount of total assets in US dollars to arrive at a measure for a company's carbon intensity. Second, we adjust this metric by the median industry-level of carbon emissions.

\section{***** Insert Figure 2 about here $* * * *$}

Tables 2 and 3 document our evidence regarding the Risk Mitigation and Investor Preference Hypotheses, respectively. First, we investigate the Risk Mitigation Hypothesis. In Table 2, Models 1-3 investigate the relationship between Scope 1 carbon emissions, Scope 2 carbon emissions and the total of Scope 1 and 2 carbon emissions and a borrower's loan spread, respectively. In all three models, the coefficient of carbon emissions on loan spreads is positive and significant thus providing initial support for our Risk Mitigation Hypothesis.

Turning to the economic interpretation of our results depicted in Table 2, we also find very meaningful results: For a one standard deviation increase in Scope 1 carbon dioxide emissions, the coefficient of 0.39 translates into an increase in the loan spread by 6.5 bps. ${ }^{11}$ For the 1,600 loans included in the sample, the average loan size is US\$ 1.49 billion and 6.5 bps thus amount to annual interest cost of US\$ 0.97 million. Alternatively, an increase in

\footnotetext{
${ }^{10}$ This means that this analysis also includes firms that do not show up as borrowers in our regression samples.

${ }^{11}$ To estimate this increase in spread, we compare predicted spreads when we vary carbon emissions by one standard deviation while setting all other independent variables to their mean.
} 
Scope 1 carbon emissions from the $5^{\text {th }}$ to the $95^{\text {th }}$ percentile translates into a spread increase of 9.5 bps or US\$ 1.4 million.

To provide a more complete picture, we find that the economic relevance of increases in Scope 2 and total carbon emissions (the sum of Scope 1 and Scope 2 emissions) is equally clear. Respectively, a one standard deviation increase in emissions translates into 5.7 bps (US\$ 0.85 million) and 7.9 bps (US\$ 1.2 million) while an increase from the $5^{\text {th }}$ to the $95^{\text {th }}$ percentile translates into 8.3 bps (US\$ 1.2 million) and 16.9 bps (US\$ 2.5 million). Thus, our results obtained thus far are also economically significant.

\section{***** Insert Table 2 about here $* * * *$}

Second, we shed light on the Investor Preference Hypothesis in Table 3. In this Table, we control for the presence of norms-constrained arrangers (NCA) in two different ways. In Panel A, NCA is a binary variable which equals one if the loan has been arranged by at least one CDP signatory. In Panel B, NCA is measured as the fraction of CDP signatories of the entire arranger syndicate for this specific loan. In both Panels, we assess the influence of the actual carbon emissions and the interaction effect between carbon emissions and the presence of NCAs on the loan spreads borrowing companies have to pay.

While the results indicate that the industry-adjusted level of carbon emissions significantly influences the loan spreads in a positive way, none of the interaction terms between the levels of carbon emissions and NCA is significant. These results are consistent across all models in Table 3 and allow us to reject the Investor Preference Hypothesis as it indicates that loans arranged by CDP signatories (i.e., by environmentally NCA) carry the same spread as loans arranged by unconstrained lenders. As before, the empirical results for the remaining control variables are consistent with the existing literature on loan pricing.

As a whole, the results of Tables 2 and 3 support our Risk Mitigation Hypothesis: Firms with higher carbon emissions face a higher cost of debt capital. This seems to suggest that firms can save substantial amounts of capital by limiting their carbon emissions relative 
to their industry peers. This benefit materializes independent of whether firms borrow from environmentally norms-constrained or -unconstrained lenders.

**** Insert Table 3 about here $* * * *$

\subsection{Additional Evidence on the Risk Mitigation Hypothesis}

Having documented supporting evidence in favor of our Risk Mitigation Hypothesis, we spare out the analysis of the existence of NCAs in this robustness test section and rather focus on the risk mitigation story such as in Table 2 .

\subsubsection{Which industries are mostly exposed to the risk mitigation effects?}

In our first additional analyses, we provide evidence on the industry variation of the empirical effects that we documented before. As we have documented in Figure 2, the extent to which industries are exposed to carbon emissions ultimately depends on the industry they are operating in. Therefore, this section sheds additional light on the claim that only environmentally sensitive industries are affected by substantial levels of carbon emissions. Furthermore, this additional analysis is also of great importance to investors and in particular lenders, as the industry is considered to be an important driver of corporate credit ratings and loan spreads.

The analysis of this industry effect is presented in Table 4 and consists of four different Panels: Panel A takes into account manufacturing and construction companies, Panel $\mathrm{B}$ focuses on public utilities and transportation, Panel $\mathrm{C}$ includes mining and agriculture, forestry, and fishing, while Panel D takes into account companies from finance, insurance, and real estate. In these four panels, we pool industries with similar levels of median industry emissions. It is nevertheless important to note that due to our approach to look at specific industry subsets, the number of observations in each of the models is significantly lower than in the previous analyses which might also in turn affect the corresponding statistical power of these models. 
The results of Table 4 can be interpreted as follows. To start with, we find consistently positive and mostly significant relations between the level of carbon emissions, in particular Scope 1 emissions, and the loan spreads. Only for Panel C, where we focus on the mining and agriculture, forestry, and fishing sectors, we are not able to establish a significant and positive relationship between the emission levels and the loan spreads.

The overall results point to the fact that not only environmentally sensitive industries, i.e. those industries that are well-known to be highly exposed to climate change risks and carbon emissions, have to pay a premium on their bank loans when they exhibit relatively high carbon emission levels. Instead, we also show that companies operating in the finance, insurance, and real estate sectors have to pay a premium when their carbon emissions are relatively high.

\subsubsection{Quantile regression results: Are the biggest emitters driving our results?}

To account for the fact that even industry- and firm-size adjusted carbon emissions might be influenced by severe outliers (both at the upper and lower end of the distribution), we repeat the analyses that we conducted in Table 2 using a quantile regression approach with bootstrapped standard errors. This exercise can be regarded as a robustness check to rule out the possibility that the firms with the highest carbon emissions in our sample are driving the results that we obtained so far. The results in all three Panels indicate that the previously documented positive and significant relation between carbon emissions and loan spreads is consistent across the entire distributions of loan spreads and emissions, i.e., the size and significance of the carbon emission coefficients are remarkably similar across the distribution. An interesting observation can be made from Panels $\mathrm{B}$ and $\mathrm{C}$ in that the control variable accounting for the presence of a reputable arranger exhibits a negative and significant relation with a company's loan spread. This implies that loans arranged by reputable arrangers (which can also be NCAs) have lower loan spreads, but only for very reputable arrangers at the 50\% or $75 \%$ reputation quantile. Similarly, loan maturity is negatively related to spreads only at 
the long end of the maturity distribution, e.g. at the $75^{\text {th }}$ percentile. In contrast an improvement of borrower profitability is most strongly related to spreads for the weakest borrower, e.g. borrowers with ROA at the $25^{\text {th }}$ percentile.

\section{***** Insert Table 5 about here $* * * *$}

\subsubsection{Assessing the influence of a company's control over carbon emissions on spreads}

Boards can exert direct control over the carbon emission levels of their companies. In order to do so, boards can put several measures in place which might influence the observed relationship between emission levels and loan spreads because the arrangers and other participating banks in the loan syndicate might take the company's level of awareness and control also into account when assessing the creditworthiness of a potential borrower. For example, in order to convince investors and other stakeholder about the board's awareness of climate change and carbon emissions, companies can externally verify the measurement and reporting of the emission levels through a third party such as an auditor. Alternatively, companies nowadays also put specific and measurable carbon emission reduction targets in place which outline the company's approach to reduce its long term carbon emission levels. The presence of such targets could thus signal the company's strong control over emission levels to investors. Yet another alternative is to introduce board-level responsibility for climate change and carbon emissions by appointing a Chief Sustainability Officer or by introducing a particular board-level committee which deals with sustainability and climate change questions. ${ }^{12}$

The three different Panels in Table 6 take account of these options. In Panel A, we assess the impact of externally verifying the carbon emissions. Across all three models of Panel A we find a positive and significant relation between Scope 1, Scope 2, and total carbon emission and the loan spreads, but only for firms which have their carbon emissions not

\footnotetext{
${ }^{12}$ Such a committee would be similar in terms of functionality and responsibility as the audit or remuneration committee that most publicly listed companies have (or are required to have).
} 
externally verified. These results can be interpreted as follows. Companies which have no external verification of their carbon emissions have to pay higher loan spreads when they exhibit higher levels carbon emissions. Because of the missing external validation of the reported carbon emissions, lenders charge a risk premium as borrowers seem to only have weak control over their emissions and lenders cannot be assured that the reported emission level reflect the actual amount of carbon emitted. On the other hand, borrowers which have their emission levels externally verified do not have to pay higher loan spreads even with relatively high emission levels.

Panel B of Table 6 investigates the influence of the presence of company-wide emission reduction plans. For this Panel, we find a consistent positive relationship between the interaction term between the emission level and the binary variable which indicates the control level of a company and the loan spread. The positive coefficient on the interaction term implies that irrespective of whether the company has emission reduction targets in place or not, it has to pay significantly higher loan spreads when the emission level is high. However, the increase in spreads tends to be higher for borrowers with weak control over their emissions,i.e, borrowers without reduction targets. ${ }^{13}$ While consistent with our initial evidence on the risk mitigation hypothesis, these findings imply that targets specified in the reduction plans might be a valuable management tool to at least partially reduce the environmental risk premium charged by lenders.

Panel C of Table 6 then goes on and takes a look whether board level responsibility for climate change and carbon emissions has a differentiating pricing effect for corporate bank loans. The results indicate that carbon emission have a positive relation with loan spreads, especially in the absence of board level responsibility for carbon emissions. That is, when companies do not have appropriate board-level responsibility in place, companies have to pay

\footnotetext{
${ }^{13}$ However, this increase is statistically significant only in Model 2 where the F-test of 3.32 indicates a significant difference between the interaction term coefficients at the $10 \%$ level.
} 
significantly higher loan spreads as compared to companies which have explicit board level responsibility for climate change and carbon emissions. This result indicates that lenders value the presence of board-level responsibility for climate change and carbon emissions.

\section{$5 \quad$ Summary and concluding comments}

This paper analyses the effects of voluntarily disclosing carbon emissions and the actually revealed level of carbon emissions for the corporate cost of debt. The central research question is whether more transparency with respect to and disclosure of actual carbon emissions levels is related to a corporation's cost of debt in a significant way. Our results document that higher transparency with respect to carbon emissions leads to more favorable loan conditions: Firms which answer the annual CDP questionnaire and voluntarily reveal their carbon emission pay significantly lower loan spreads as compared to firms which do not disclose their emissions data. On average, firms that receive the CDP questionnaire and decide to disclose their emissions can save up to US\$ 1.2 million per annum in interest payments. This is an economically significant amount. In our analyses, we also address the question whether the effect of carbon emissions disclosure is same for firms with different levels of information uncertainty. We find that voluntary disclosure of carbon emissions is limited to borrowers with a high level of information uncertainty

In the second part of the paper, we focus on those CDP firms which also disclose their carbon emissions. To be more precise, we examine whether the actual level of carbon emissions affect the loan spread. Our analyses reveal that higher industry- and firm-sizeadjusted carbon emissions have a significantly positive effect on loan spreads. Economically, we find that a one standard deviation increase in our relative carbon emissions measures can lead to an average increase in interest costs of US\$ 0.85 to 1.2 million per annum. As this spread premium is unaffected by the presence of norms-constrained investors, we conclude in favor of the Risk Mitigation over the Investor Preference Hypothesis. 
Our results suggest that financial markets and in particular for lenders take into account extra-financial information on firms' environmental performance when assessing the creditworthiness of borrowers because they are aware of potential future risks that can arise for firms with poor environmental performance. Furthermore, Our results suggest policy implication for firms and regulators. First, firms can mitigate this environmental risk premium by signaling their strong level of control over their environmental performance to lenders. External verification of carbon emissions, emission reduction targets and board-level responsibility for climate change and carbon emissions are valuable management tools in this respect. Second, the substantial size of the environmental risk premium provides firms with a strong incentive to reduce and manage their carbon emissions. For regulators and governments, such corporate self-regulation reduces - at least to some extent - the need for explicit regulation. 


\section{Appendix}

Table A1

Variable definitions and sources

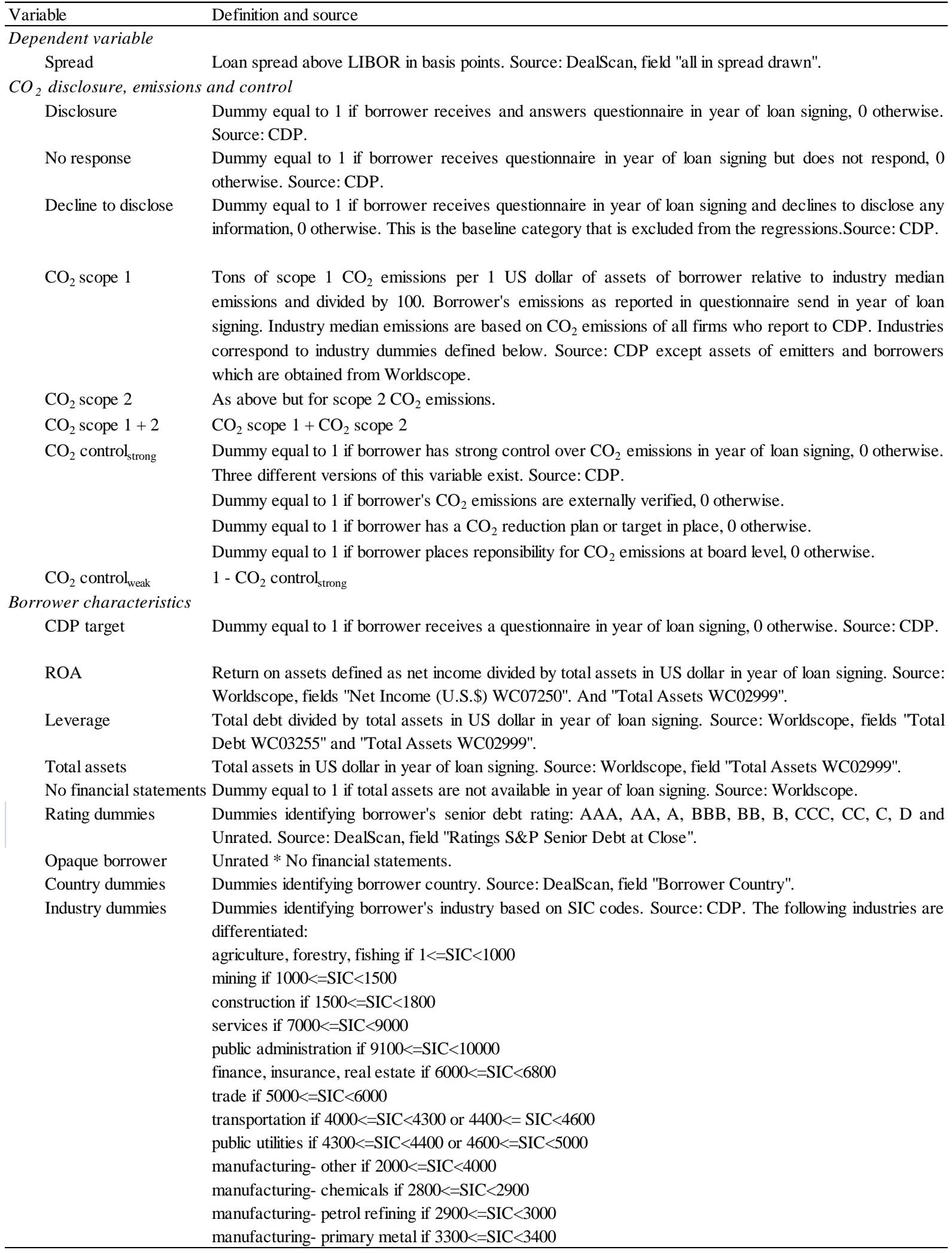


Table A1 (continued)

Variable definitions and sources

\begin{tabular}{|c|c|}
\hline Variable & Definition and source \\
\hline \multicolumn{2}{|l|}{ Loan characteristics } \\
\hline $\begin{array}{l}\text { Norms constrained } \\
\text { arranger (NCA) }\end{array}$ & $\begin{array}{l}\text { Dummy equal to } 1 \text { if at least one CDP signatory is among the loan's lead arrangers, } 0 \text { otherwise. Source: } \\
\text { CDP for signatories, DealScan for lead arrangers. }\end{array}$ \\
\hline Reputable arranger & $\begin{array}{l}\text { Dummy equal to } 1 \text { if at least one arranger belongs to top } 10 \text { arrangers in terms of market share in the year } \\
\text { before loan signing. Source: Own calculations based on DealScan, field "Lead arranger", market shares } \\
\text { are based on loan size. }\end{array}$ \\
\hline Loan maturity & Tranche maturity in months. Source: DealScan, field "Tenor / Maturity". \\
\hline Loan size & Tranche size in US dollar. Source: DealScan, field "Tranche Size (Converted)". \\
\hline Multiple-tranche deal & Dummy equal to 1 if loan tranche belongs to deal with multiple tranches, 0 otherwise. Source: DealScan. \\
\hline Performance pricing & $\begin{array}{l}\text { Dummy equal to } 1 \text { if loan contract includes performance pricing, } 0 \text { otherwise. Source: Dealscan, field } \\
\text { "Performance Pricing". }\end{array}$ \\
\hline Financial covenants & $\begin{array}{l}\text { Dummy equal to } 1 \text { if loan contract includes financial covenants, } 0 \text { otherwise. Source: Dealscan, field } \\
\text { "Covenants Financial: All Covenants Financial". }\end{array}$ \\
\hline Multiple base rates & $\begin{array}{l}\text { Dummy equal to } 1 \text { if loan contract includes multiple base rates, } 0 \text { otherwise. Source: Dealscan, field "Base } \\
\text { Rate / Margin". }\end{array}$ \\
\hline Term loan & $\begin{array}{l}\text { Dummy equal to } 1 \text { if loan is term loan, } 0 \text { otherwise. Source: DealScan, fields "SpecificInstrument" and } \\
\text { "Specific TrancheType"., } 0 \text { otherwise }\end{array}$ \\
\hline Senior & Dummy equal to 1 if loan is senior or senior subordinated, 0 otherwise. Source: DealScan, field "Seniority". \\
\hline Secured & Dummy equal to 1 if loan is secured, 0 otherwise. Source: DealScan, field "Secured / Unsecured". \\
\hline Loan purpose dummies & $\begin{array}{l}\text { Dummies identifying different loan purposes: corporate restructuring, financial structure, general corporate } \\
\text { purpose, undisclosed. Source: DealScan, field "Primary Purpose". }\end{array}$ \\
\hline Year dummies & $\begin{array}{l}\text { Dummies identifying different years of loan signing: } 2007 \text { to 2013. Source: DealScan, field "Deal Active } \\
\text { Date". }\end{array}$ \\
\hline
\end{tabular}


Table A2

Descriptive statistics

\begin{tabular}{|c|c|c|c|c|c|c|}
\hline Variable & Mean & Median & $\begin{array}{l}\text { Standard } \\
\text { deviation }\end{array}$ & Minimum & Maximum & $\mathrm{N}$ \\
\hline \multicolumn{7}{|c|}{ Panel A: Sample of loans used in analyses of emission transparency } \\
\hline $\ln ($ spread in bp) & 5.18 & 5.30 & 0.83 & -0.51 & 7.60 & 17,643 \\
\hline Spread in bp & 238.23 & 200.00 & 188.35 & 0.60 & $2,000.00$ & 17,643 \\
\hline CDP target & 0.28 & 0 & 0.45 & 0 & 1 & 17,643 \\
\hline Disclosure & 0.17 & 0 & 0.37 & 0 & 1 & 17,643 \\
\hline No response & 0.09 & 0 & 0.29 & 0 & 1 & 17,643 \\
\hline Decline to disclose & 0.02 & 0 & 0.16 & 0 & 1 & 17,643 \\
\hline Unrated & 0.55 & 1 & 0.50 & 0 & 1 & 17,643 \\
\hline No financial statements & 0.49 & 0 & 0.50 & 0 & 1 & 17,643 \\
\hline Opaque & 0.70 & 1 & 0.46 & 0 & 1 & 17,643 \\
\hline Norms constrained arranger & 0.65 & 1 & 0.48 & 0 & 1 & 17,643 \\
\hline Reputable arranger & 0.58 & 1 & 0.49 & 0 & 1 & 17,643 \\
\hline $\ln ($ Loan size in $\$)$ & 18.99 & 19.11 & 1.50 & 11.51 & 24.62 & 17,643 \\
\hline Loan size in $\$$ mio & 497.00 & 200.00 & $1,100.00$ & 0.10 & $49,000.00$ & 17,643 \\
\hline $\ln$ (Loan maturity) & 3.78 & 4.09 & 0.64 & 0.00 & 6.59 & 17,643 \\
\hline Loan maturity (months) & 51.25 & 60.00 & 26.52 & 1.00 & 725.00 & 17,643 \\
\hline Multiple-tranche deal & 0.55 & 1 & 0.50 & 0 & 1 & 17,643 \\
\hline Performance pricing & 0.22 & 0 & 0.42 & 0 & 1 & 17,643 \\
\hline Financial covenants & 0.37 & 0 & 0.48 & 0 & 1 & 17,643 \\
\hline Multiple base rates & 0.25 & 0 & 0.43 & 0 & 1 & 17,643 \\
\hline Term loan & 0.46 & 0 & 0.50 & 0 & 1 & 17,643 \\
\hline Senior & 1.00 & 1 & 0.06 & 0 & 1 & 17,643 \\
\hline Secured & 0.41 & 0 & 0.49 & 0 & 1 & 17,643 \\
\hline \multicolumn{7}{|c|}{ Panel B: Sample of loans used in analysis of $\mathrm{CO}_{2}$ emissions } \\
\hline $\ln ($ spread in bp) & 4.79 & 4.91 & 0.88 & 0.00 & 7.03 & 1,600 \\
\hline Spread in bp & 164.61 & 135.00 & 126.71 & 1.00 & $1,125.00$ & 1,600 \\
\hline $\mathrm{CO}_{2}$ scope 1 & 0.05 & 0.01 & 0.14 & 0.00 & 1.12 & 1,600 \\
\hline $\mathrm{CO}_{2}$ scope 2 & 0.03 & 0.01 & 0.07 & 0.00 & 0.80 & 1,600 \\
\hline $\mathrm{CO}_{2}$ scope $1+2$ & 0.08 & 0.03 & 0.17 & 0.00 & 1.28 & 1,600 \\
\hline $\mathrm{CO}_{2}$ control $_{\text {strong-externally verified emissions scope } 1}$ & 0.50 & 0 & 0.50 & 0 & 1 & 1,600 \\
\hline $\mathrm{CO}_{2}$ control $_{\text {strong-externally verified emissions scope } 2}$ & 0.39 & 0 & 0.49 & 0 & 1 & 1,600 \\
\hline $\mathrm{CO}_{2}$ control $_{\text {strong-externally verified emissions scope } 1+2}$ & 0.39 & 0 & 0.49 & 0 & 1 & 1,600 \\
\hline $\mathrm{CO}_{2}$ control $_{\text {strong-reduction target or plan }}$ & 0.74 & 1 & 0.44 & 0 & 1 & 1,600 \\
\hline $\mathrm{CO}_{2}$ control $_{\text {strong-board level reponsability }}$ & 0.59 & 1 & 0.49 & 0 & 1 & 1,600 \\
\hline Norms constrained arranger & 0.85 & 1 & 0.36 & 0 & 1 & 1,600 \\
\hline Reputable arranger & 0.84 & 1 & 0.37 & 0 & 1 & 1,600 \\
\hline $\ln ($ Loan size in $\$)$ & 20.41 & 20.50 & 1.26 & 15.93 & 24.62 & 1,600 \\
\hline Loan size in $\$$ mio & $1,490.00$ & 800.00 & $2,360.00$ & 8.25 & $49,000.00$ & 1,600 \\
\hline $\ln$ (Loan maturity) & 3.66 & 3.97 & 0.66 & 0.00 & 6.59 & 1,600 \\
\hline Loan maturity (months) & 46.22 & 53.00 & 27.21 & 1.00 & 725.00 & 1,600 \\
\hline Multiple-tranche deal & 0.47 & 0 & 0.50 & 0 & 1 & 1,600 \\
\hline Performance pricing & 0.24 & 0 & 0.42 & 0 & 1 & 1,600 \\
\hline Financial covenants & 0.28 & 0 & 0.45 & 0 & 1 & 1,600 \\
\hline Multiple base rates & 0.16 & 0 & 0.37 & 0 & 1 & 1,600 \\
\hline Term loan & 0.29 & 0 & 0.45 & 0 & 1 & 1,600 \\
\hline Senior & 1.00 & 1 & 0.05 & 0 & 1 & 1,600 \\
\hline Secured & 0.15 & 0 & 0.35 & 0 & 1 & 1,600 \\
\hline ROA & 0.04 & 0.04 & 0.08 & -0.71 & 0.77 & 1,600 \\
\hline Leverage & 0.30 & 0.29 & 0.15 & 0.00 & 0.81 & 1,600 \\
\hline $\ln$ (Total assets in $\${ }^{\prime} 000$ ) & 16.78 & 16.79 & 1.34 & 11.72 & 21.51 & 1,600 \\
\hline Total assets in $\$$ bn & 50.50 & 19.60 & 117.00 & 0.12 & $2,190.00$ & 1,600 \\
\hline
\end{tabular}




\section{References}

Armstrong, C. S., Guay, W. R., \& Weber, J. P. (2010). The Role of Information and Financial Reporting in Corporate Governance and Debt Contracting. Journal of Accounting and Economics, 50, 179-234.

Bauer, R., \& Hann, D. (2010). Corporate Environmental Management and Credit Risk. ECCE Working Paper. University Maastricht, The European Centre for Corporate Engagement.

Beyer, A., Cohen, D. A., Lys, T. Z., \& Walther, B. R. (2010). The Financial Reporting Environment: Review of the Recent Literature. Journal of Accounting and Economics, 50, 296-343.

CDP. (2015a). Catalyzing business and government action. Retrieved from the World Wide Web (12 March 2015): https://www.cdp.net/en-US/Pages/About-Us.aspx.

CDP. (2015b). Become a CDP investor signatory. Retrieved from the World Wide Web (12 March 2015): https://www.cdp.net/en-US/Programmes/Pages/becoming-a-signatory.as px.

Chava, S. (2014). Environmental Externalities and Cost of Capital. Management Science, 60(9), 2223-2247.

Clark, G. L., Feiner, A., \& Viehs, M. (2015). From the Stockholder to the Stakeholder: How Sustainability Can Drive Financial Outperformance. Research Paper by the University of Oxford Smith School of Enterprise and the Environment and Arabesque Asset Management (March 2015).

Diamond, D. W., \& Verrecchia, R. E. (1991). Disclosure, Liquidity, and the Cost of Capital. Journal of Finance, 46(4), 1325-1359.

Friede, G., Busch, T., \& Bassen, A. (2015). ESG and Financial Performance: Aggregated Evidence from more than 2000 Empirical Studies. Journal of Sustainable Finance \& Investment, 5(4), 210-233. 
Godfrey, P. C., Merrill, C. B., \& Hansen, J. M. (2009). The Relationship between Corporate Social Responsibility and Shareholder Value: An Empirical Test of the Risks Management Hypothesis. Strategic Management Journal, 30, 425-445.

Gollier, C. \& Pouget, S. (2012). Asset Prices and Corporate Behavior with Socially Responsible Investors. Working Paper: Toulouse School of Economics.

Goss, A., \& Roberts, G. S. (2011). The Impact of Corporate Social Responsibility on the Cost of Bank Loans. Journal of Banking and Finance, 35, 1794-1810.

Heinkel, R., Kraus, A., \& Zechner, J. (2001). The Effect of Green Investment on Corporate Behavior. Journal of Financial and Quantitative Analysis, 36(4), 431-449.

Hong, H., \& Kacperczyk, M. (2009). The Price of Sin: The Effects of Social Norms on Markets. Journal of Financial Economics, 93(1), 15-36.

Lambert, R., Leuz, C., \& Verrecchia, R. E. (2007). Accounting Information, Disclosure, and the Cost of Capital. Journal of Accounting Research, 45(2), 385-420.

Sharfman, M. P., \& Fernando, C. S. (2008). Environmental Risk Management and the Cost of Capital. Strategic Management Journal, 29, 569-592. 
Figure 1

Cost of debt for different borrower types

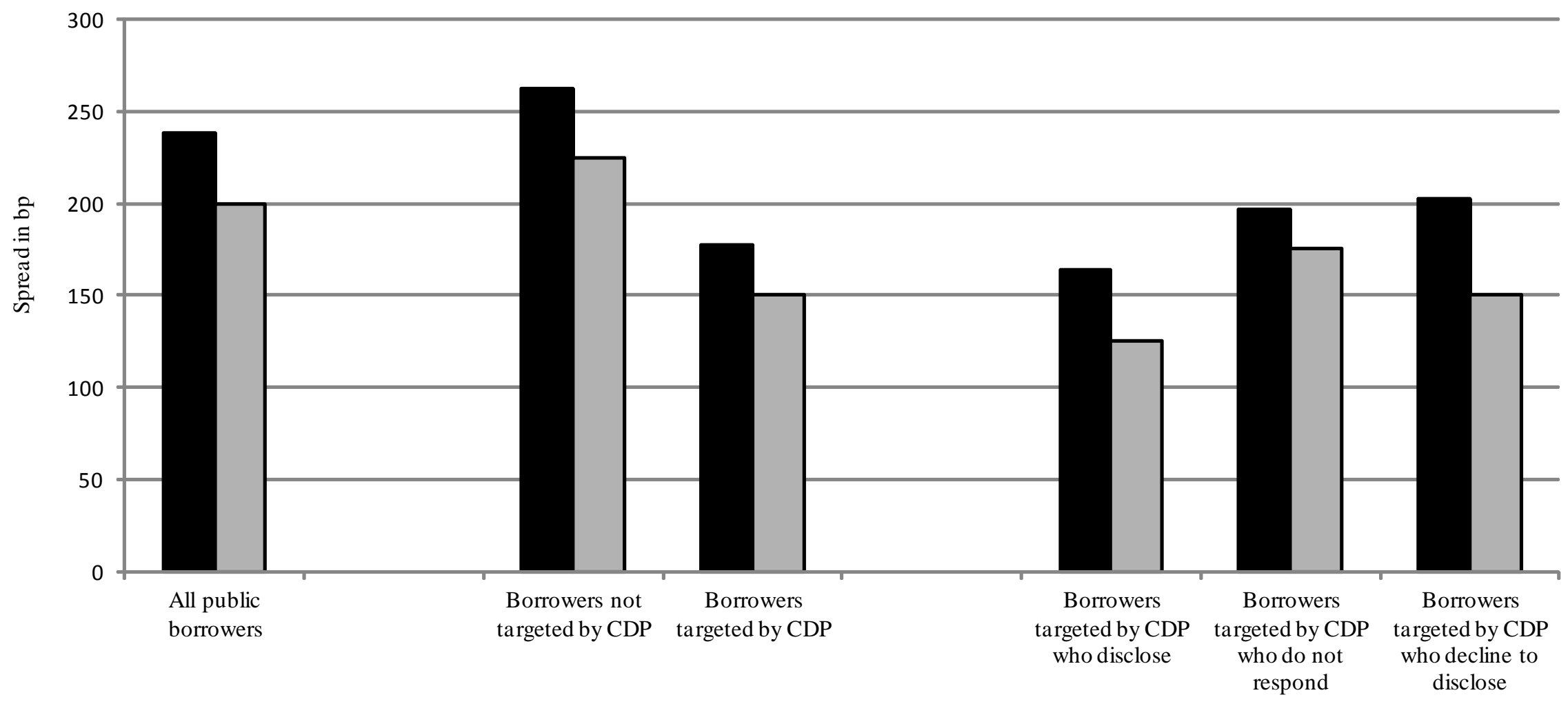

- Meanspread $\mathbf{D}$ Median spread 
Figure 2

Median $\mathrm{CO}_{2}$ emissions by industry group

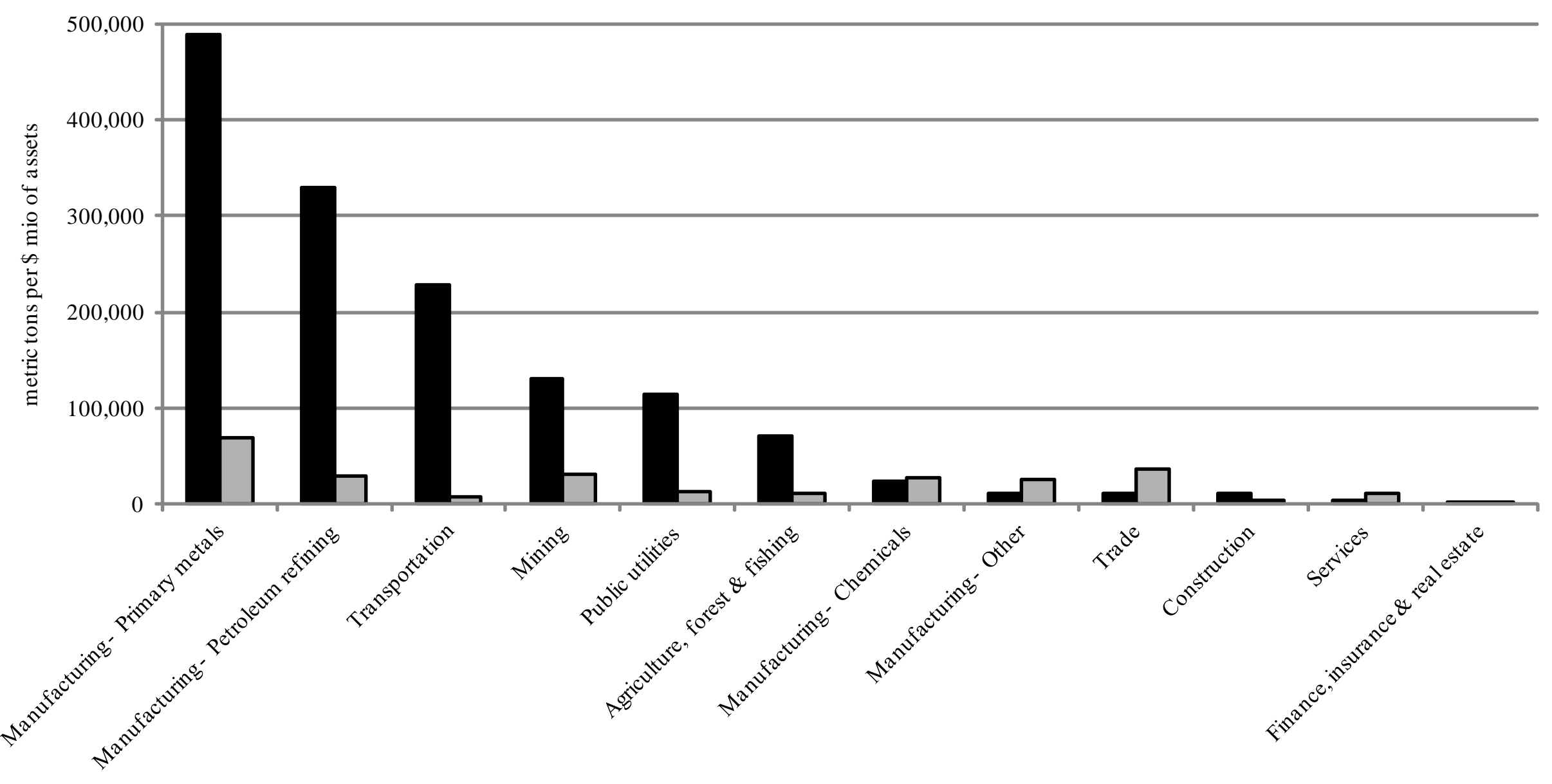

- Scope 1 QScope 2 
Table 1

Voluntary Disclosure

\begin{tabular}{|c|c|c|c|c|c|}
\hline \multirow{3}{*}{$\mathrm{CO}_{2}$ disclosure } & \multicolumn{5}{|c|}{$\ln ($ spread in bp) } \\
\hline & \multirow[t]{2}{*}{$(1)$} & \multirow[t]{2}{*}{$(2)$} & \multirow[t]{2}{*}{$(3)$} & \multirow[t]{2}{*}{$(4)$} & \multirow[t]{2}{*}{$(5)$} \\
\hline & & & & & \\
\hline \multirow[t]{2}{*}{ Disclosure } & & $-0.11 *$ & -0.04 & -0.04 & -0.04 \\
\hline & & $(-1.79)$ & $(-0.65)$ & $(-0.65)$ & $(-0.71)$ \\
\hline \multirow[t]{2}{*}{ No response } & & -0.07 & -0.07 & -0.07 & -0.07 \\
\hline & & $(-1.30)$ & $(-1.27)$ & $(-1.27)$ & $(-1.23)$ \\
\hline \multirow[t]{2}{*}{ Disclosure $*$ Opaque borrower } & & & $-0.12 * * *$ & $-0.14 *$ & $-0.10 * *$ \\
\hline & & & $(-3.01)$ & $(-1.72)$ & $(-2.20)$ \\
\hline \multirow[t]{2}{*}{ Disclosure $*$ Opaque borrower $*$ NCA } & & & & 0.03 & \\
\hline & & & & $(0.32)$ & \\
\hline \multicolumn{6}{|l|}{ Borrower characteristics } \\
\hline \multirow[t]{2}{*}{ CDP target } & $-0.13 * * *$ & -0.05 & -0.05 & -0.05 & \\
\hline & $(-6.63)$ & $(-0.84)$ & $(-0.82)$ & $(-0.81)$ & \\
\hline \multirow[t]{2}{*}{ Unrated } & $1.11 * * *$ & $1.10 * * *$ & $1.14 * * *$ & $1.15 * * *$ & $1.16 * * *$ \\
\hline & $(5.18)$ & $(5.13)$ & $(5.27)$ & $(5.29)$ & $(5.06)$ \\
\hline \multirow[t]{2}{*}{ No financial statements } & $0.05 * * *$ & $0.05 * * *$ & $0.06 * * *$ & $0.06 * * *$ & $0.26 * * *$ \\
\hline & $(4.15)$ & $(4.18)$ & $(4.98)$ & $(4.98)$ & $(4.60)$ \\
\hline \multicolumn{6}{|l|}{ Loan characteristics } \\
\hline \multirow[t]{2}{*}{ Norms constrained arranger (NCA) } & & & & -0.01 & \\
\hline & & & & $(-0.99)$ & \\
\hline \multirow[t]{2}{*}{ Reputable arranger } & $-0.12 * * *$ & $-0.12 * * *$ & $-0.12 * * *$ & $-0.12 * * *$ & $-0.10 * * *$ \\
\hline & $(-9.20)$ & $(-9.19)$ & $(-9.08)$ & $(-8.86)$ & $(-3.14)$ \\
\hline \multirow[t]{2}{*}{$\ln ($ Loan size $)$} & $-0.08 * * *$ & $-0.08 * * *$ & $-0.08 * * *$ & $-0.08 * * *$ & $-0.06 * * *$ \\
\hline & $(-14.67)$ & $(-14.61)$ & $(-14.65)$ & $(-14.47)$ & $(-5.12)$ \\
\hline \multirow[t]{2}{*}{$\ln$ (Loan maturity) } & $0.03 * *$ & $0.03 * *$ & $0.03 * *$ & $0.03 * *$ & $0.05 *$ \\
\hline & $(2.34)$ & $(2.25)$ & $(2.29)$ & $(2.29)$ & $(1.79)$ \\
\hline \multirow[t]{2}{*}{ Multiple-tranche deal } & $0.10 * * *$ & $0.10 * * *$ & $0.10 * * *$ & $0.10 * * *$ & $0.10 * * *$ \\
\hline & $(7.07)$ & $(7.08)$ & $(7.00)$ & $(7.06)$ & $(3.56)$ \\
\hline \multirow[t]{2}{*}{ Performance pricing } & $-0.10 * * *$ & $-0.10 * * *$ & $-0.10 * * *$ & $-0.10 * * *$ & -0.00 \\
\hline & $(-5.35)$ & $(-5.37)$ & $(-5.38)$ & $(-5.38)$ & $(-0.03)$ \\
\hline \multirow[t]{2}{*}{ Financial covenants } & $-0.04 * *$ & $-0.04 * *$ & $-0.04 * *$ & $-0.04 * *$ & 0.04 \\
\hline & $(-2.49)$ & $(-2.53)$ & $(-2.47)$ & $(-2.43)$ & $(1.02)$ \\
\hline \multirow[t]{2}{*}{ Multiple base rates } & $-0.05 * *$ & $-0.05 * *$ & $-0.05 * *$ & $-0.05 * *$ & 0.03 \\
\hline & $(-2.54)$ & $(-2.51)$ & $(-2.52)$ & $(-2.48)$ & $(0.73)$ \\
\hline \multirow[t]{2}{*}{ Term loan } & $0.23 * * *$ & $0.23 * * *$ & $0.22 * * *$ & $0.22 * * *$ & $0.11 * * *$ \\
\hline & $(19.75)$ & $(19.64)$ & $(19.56)$ & $(19.57)$ & $(3.91)$ \\
\hline Senior & $-1.13 * * *$ & $-1.12 * * *$ & $-1.12 * * *$ & $-1.12 * * *$ & $-1.31 * * *$ \\
\hline & $(-12.42)$ & $(-12.37)$ & $(-12.38)$ & $(-12.37)$ & $(-5.62)$ \\
\hline Secured & $0.20 * * *$ & $0.20 * * *$ & $0.20 * * *$ & $0.20 * * *$ & $0.19 * * *$ \\
\hline & $(14.95)$ & $(14.98)$ & $(15.04)$ & $(15.05)$ & $(5.84)$ \\
\hline Adjusted R-squared & 0.584 & 0.585 & 0.585 & 0.585 & 0.607 \\
\hline Observations & 17,643 & 17,643 & 17,643 & 17,643 & 5,017 \\
\hline
\end{tabular}

Note: This table shows OLS regressions with heteroscedasticity robust standard errors clustered by borrower. Regressions 1 to 4 are based on a sample of public firms, regression 5 is based on a sub-sample of public firms that received a questionnaire from CDP in the year of loan signing. For each independent variable, the top row shows the coefficient and the bottom row shows the t-statistic. All regressions include dummies for loan characteristics including loan purpose and year of loan signing as well as borrower characteristics including rating, industry and country. The excluded disclosure class is "Decline to disclose". The excluded rating class is AAA. *** $1 \%, * * 5 \%, * 10 \%$ significance. 
Table 2

Risk Mitigation

\begin{tabular}{|c|c|c|c|}
\hline \multirow{3}{*}{$\mathrm{CO}_{2}$ emissions } & \multicolumn{3}{|c|}{$\ln ($ spread in bp $)$} \\
\hline & \multirow[t]{2}{*}{$(1)$} & \multirow[t]{2}{*}{$(2)$} & \multirow[t]{2}{*}{ (3) } \\
\hline & & & \\
\hline $\mathrm{CO}_{2}$ scope 1 & $\begin{array}{l}0.39 * * \\
(2.39)\end{array}$ & & \\
\hline $\mathrm{CO}_{2}$ scope 2 & \multirow{2}{*}{\multicolumn{2}{|c|}{$\begin{array}{l}0.66 \text { *** } \\
(3.63)\end{array}$}} & \\
\hline $\mathrm{CO}_{2}$ scope $1+2$ & & & $\begin{array}{l}0.38 \text { *** } \\
(3.40)\end{array}$ \\
\hline \multicolumn{4}{|c|}{ Borrower characteristics } \\
\hline ROA & $\begin{array}{l}-0.63 * * \\
(-2.12)\end{array}$ & $\begin{array}{l}-0.64 \text { ** } \\
(-2.07)\end{array}$ & $\begin{array}{l}-0.66 \text { ** } \\
(-2.23)\end{array}$ \\
\hline Leverage & $\begin{array}{r}-0.01 \\
(-0.07)\end{array}$ & $\begin{array}{r}-0.06 \\
(-0.41)\end{array}$ & $\begin{array}{r}-0.06 \\
(-0.40)\end{array}$ \\
\hline $\ln$ (Total assets) & $\begin{array}{l}-0.10 * * * \\
(-4.91)\end{array}$ & $\begin{array}{l}-0.10 * * * \\
(-4.80)\end{array}$ & $\begin{array}{l}-0.10 * * * \\
(-4.69)\end{array}$ \\
\hline \multicolumn{4}{|l|}{ Loan characteristics } \\
\hline Reputable arranger & $\begin{array}{l}-0.13 \text { ** } \\
(-2.49)\end{array}$ & $\begin{array}{l}-0.13 \text { ** } \\
(-2.53)\end{array}$ & $\begin{array}{l}-0.13 \text { ** } \\
(-2.51)\end{array}$ \\
\hline $\ln ($ Loan size $)$ & $\begin{array}{r}-0.01 \\
(-0.61)\end{array}$ & $\begin{array}{r}-0.01 \\
(-0.65)\end{array}$ & $\begin{array}{r}-0.01 \\
(-0.67)\end{array}$ \\
\hline $\ln$ (Loan maturity) & $\begin{array}{r}-0.03 \\
(-0.84)\end{array}$ & $\begin{array}{r}-0.03 \\
(-0.80)\end{array}$ & $\begin{array}{r}-0.03 \\
(-0.80)\end{array}$ \\
\hline Multiple-tranche deal & $\begin{array}{l}0.09 * * \\
(2.17)\end{array}$ & $\begin{array}{l}0.09 \text { ** } \\
(2.17)\end{array}$ & $\begin{array}{l}0.09 * * \\
(2.18)\end{array}$ \\
\hline Performance pricing & $\begin{array}{l}0.08 * \\
(1.66)\end{array}$ & $\begin{array}{c}0.09 * \\
(1.85)\end{array}$ & $\begin{array}{l}0.08 * \\
(1.65)\end{array}$ \\
\hline Financial covenants & $\begin{array}{r}0.03 \\
(0.72)\end{array}$ & $\begin{array}{r}0.04 \\
(0.93)\end{array}$ & $\begin{array}{r}0.04 \\
(0.77)\end{array}$ \\
\hline Multiple base rates & $\begin{array}{r}0.01 \\
(0.22)\end{array}$ & $\begin{array}{r}-0.00 \\
(-0.06)\end{array}$ & $\begin{array}{r}0.01 \\
(0.22)\end{array}$ \\
\hline Term loan & $\begin{array}{l}0.09 * * \\
(2.12)\end{array}$ & $\begin{array}{l}0.09 * * \\
(2.03)\end{array}$ & $\begin{array}{l}0.09 * * \\
(2.08)\end{array}$ \\
\hline Senior & $\begin{array}{l}-1.60 * * * \\
(-2.94)\end{array}$ & $\begin{array}{l}-1.62 * * * \\
(-2.97)\end{array}$ & $\begin{array}{l}-1.60 * * * \\
(-2.95)\end{array}$ \\
\hline Secured & $\begin{array}{l}0.17 \text { ** } \\
(2.50)\end{array}$ & $\begin{array}{l}0.17 \text { ** } \\
(2.54)\end{array}$ & $\begin{array}{l}0.17 \text { ** } \\
(2.58)\end{array}$ \\
\hline Adjusted R-squared & 0.667 & 0.667 & 0.668 \\
\hline Observations & 1,600 & 1,600 & 1,600 \\
\hline
\end{tabular}

Note: This table shows OLS regressions with heteroscedasticity robust standard errors clustered by borrower. For each independent variable, the top row shows the coefficient and the bottom row shows the tstatistic. All regressions include dummies for loan characteristics including loan purpose and year of loan signing as well as borrower characteristics including rating, industry and country. $* * * 1 \%, * * 5 \%, *$ $10 \%$ significance. 
Table 3

Risk Mitigation Versus Investor Preference

\begin{tabular}{|c|c|c|c|c|c|c|}
\hline & \multicolumn{6}{|c|}{$\ln ($ spread in bp) } \\
\hline & \multicolumn{3}{|c|}{$\begin{array}{l}\text { Panel A: Presence of norms } \\
\text { constraint arrangers }\end{array}$} & \multicolumn{3}{|c|}{$\begin{array}{c}\text { Panel B: Prominance of norms } \\
\text { constraint arrangers }\end{array}$} \\
\hline & $(1)$ & $(2)$ & (3) & $(1)$ & $(2)$ & $(3)$ \\
\hline \multicolumn{7}{|l|}{$\mathrm{CO}_{2}$ emissions } \\
\hline $\mathrm{CO}_{2}$ scope 1 & $\begin{array}{l}0.52 * * \\
(2.04)\end{array}$ & & & $\begin{array}{l}0.52 \text { ** } \\
(2.32)\end{array}$ & & \\
\hline $\mathrm{CO}_{2}$ scope 2 & & $\begin{array}{r}0.75 \\
(1.32)\end{array}$ & & & $\begin{array}{c}0.71 * \\
(1.91)\end{array}$ & \\
\hline $\mathrm{CO}_{2}$ scope $1+2$ & & & $\begin{array}{l}0.51 * * \\
(2.39)\end{array}$ & & & $\begin{array}{l}0.51 * * * \\
(2.86)\end{array}$ \\
\hline $\mathrm{CO}_{2}$ scope $1 * \mathrm{NCA}$ & $\begin{array}{r}-0.15 \\
(-0.72)\end{array}$ & & & $\begin{array}{r}-0.24 \\
(-0.99)\end{array}$ & & \\
\hline $\mathrm{CO}_{2}$ scope $2 * \mathrm{NCA}$ & & $\begin{array}{r}-0.09 \\
(-0.16)\end{array}$ & & & $\begin{array}{r}-0.09 \\
(-0.20)\end{array}$ & \\
\hline$\left(\mathrm{CO}_{2}\right.$ scope $\left.1+2\right) * \mathrm{NCA}$ & & & $\begin{array}{r}-0.14 \\
(-0.71)\end{array}$ & & & $\begin{array}{r}-0.21 \\
(-1.07)\end{array}$ \\
\hline \multicolumn{7}{|l|}{ Borrower characteristics } \\
\hline ROA & $\begin{array}{l}-0.64 * * \\
(-2.15)\end{array}$ & $\begin{array}{l}-0.65 * * \\
(-2.06)\end{array}$ & $\begin{array}{l}-0.67 * * \\
(-2.26)\end{array}$ & $\begin{array}{l}-0.64 * * \\
(-2.15)\end{array}$ & $\begin{array}{l}-0.64 * * \\
(-2.05)\end{array}$ & $\begin{array}{l}-0.67 * * \\
(-2.26)\end{array}$ \\
\hline Leverage & $\begin{array}{r}-0.01 \\
(-0.07)\end{array}$ & $\begin{array}{r}-0.06 \\
(-0.41)\end{array}$ & $\begin{array}{r}-0.06 \\
(-0.41)\end{array}$ & $\begin{array}{r}-0.00 \\
(-0.03)\end{array}$ & $\begin{array}{r}-0.06 \\
(-0.38)\end{array}$ & $\begin{array}{r}-0.06 \\
(-0.39)\end{array}$ \\
\hline $\ln$ (Total assets) & $\begin{array}{l}-0.10 * * * \\
(-5.01)\end{array}$ & $\begin{array}{l}-0.10 * * * \\
(-4.89)\end{array}$ & $\begin{array}{l}-0.10 * * * \\
(-4.79)\end{array}$ & $\begin{array}{l}-0.10 * * * \\
(-5.08)\end{array}$ & $\begin{array}{l}-0.10 * * * \\
(-4.93)\end{array}$ & $\begin{array}{l}-0.10 * * * \\
(-4.83)\end{array}$ \\
\hline \multicolumn{7}{|l|}{ Loan characteristics } \\
\hline Norms constrained arranger (NCA) & $\begin{array}{r}0.02 \\
(0.40)\end{array}$ & $\begin{array}{r}0.01 \\
(0.21)\end{array}$ & $\begin{array}{r}0.03 \\
(0.39)\end{array}$ & $\begin{array}{r}0.06 \\
(0.88)\end{array}$ & $\begin{array}{r}0.05 \\
(0.65)\end{array}$ & $\begin{array}{r}0.06 \\
(0.84)\end{array}$ \\
\hline Reputable arranger & $\begin{array}{l}-0.13 * * \\
(-2.54)\end{array}$ & $\begin{array}{l}-0.13 * * \\
(-2.57)\end{array}$ & $\begin{array}{l}-0.13 * * \\
(-2.55)\end{array}$ & $\begin{array}{l}-0.12 * * \\
(-2.28)\end{array}$ & $\begin{array}{l}-0.13 * * \\
(-2.35)\end{array}$ & $\begin{array}{l}-0.12 * * \\
(-2.29)\end{array}$ \\
\hline $\ln ($ Loan size $)$ & $\begin{array}{r}-0.01 \\
(-0.60)\end{array}$ & $\begin{array}{r}-0.01 \\
(-0.65)\end{array}$ & $\begin{array}{r}-0.01 \\
(-0.66)\end{array}$ & $\begin{array}{r}-0.01 \\
(-0.60)\end{array}$ & $\begin{array}{r}-0.01 \\
(-0.64)\end{array}$ & $\begin{array}{r}-0.01 \\
(-0.67)\end{array}$ \\
\hline $\ln$ (Loan maturity) & $\begin{array}{r}-0.03 \\
(-0.89)\end{array}$ & $\begin{array}{r}-0.03 \\
(-0.82)\end{array}$ & $\begin{array}{r}-0.03 \\
(-0.85)\end{array}$ & $\begin{array}{r}-0.03 \\
(-0.86)\end{array}$ & $\begin{array}{r}-0.03 \\
(-0.80)\end{array}$ & $\begin{array}{r}-0.03 \\
(-0.83)\end{array}$ \\
\hline Multiple-tranche deal & $\begin{array}{l}0.08 * * \\
(2.13)\end{array}$ & $\begin{array}{l}0.08 * * \\
(2.14)\end{array}$ & $\begin{array}{l}0.08 * * \\
(2.15)\end{array}$ & $\begin{array}{l}0.08 * * \\
(2.14)\end{array}$ & $\begin{array}{l}0.08 * * \\
(2.14)\end{array}$ & $\begin{array}{l}0.08 * * \\
(2.14)\end{array}$ \\
\hline Performance pricing & $\begin{array}{l}0.08 * \\
(1.67)\end{array}$ & $\begin{array}{l}0.09 * \\
(1.85)\end{array}$ & $\begin{array}{l}0.08 * \\
(1.65)\end{array}$ & $\begin{array}{l}0.08 * \\
(1.65)\end{array}$ & $\begin{array}{l}0.09 * \\
(1.84)\end{array}$ & $\begin{array}{r}0.08 \\
(1.64)\end{array}$ \\
\hline Financial covenants & $\begin{array}{r}0.03 \\
(0.70)\end{array}$ & $\begin{array}{r}0.04 \\
(0.93)\end{array}$ & $\begin{array}{r}0.04 \\
(0.77)\end{array}$ & $\begin{array}{r}0.03 \\
(0.71)\end{array}$ & $\begin{array}{r}0.04 \\
(0.92)\end{array}$ & $\begin{array}{r}0.04 \\
(0.78)\end{array}$ \\
\hline Multiple base rates & $\begin{array}{r}0.01 \\
(0.23)\end{array}$ & $\begin{array}{r}-0.00 \\
(-0.05)\end{array}$ & $\begin{array}{r}0.01 \\
(0.23)\end{array}$ & $\begin{array}{r}0.01 \\
(0.18)\end{array}$ & $\begin{array}{r}-0.00 \\
(-0.08)\end{array}$ & $\begin{array}{r}0.01 \\
(0.19)\end{array}$ \\
\hline Term loan & $\begin{array}{l}0.09 * * \\
(2.12)\end{array}$ & $\begin{array}{l}0.09 * * \\
(2.02)\end{array}$ & $\begin{array}{l}0.09 \text { ** } \\
(2.07)\end{array}$ & $\begin{array}{l}0.09 \text { ** } \\
(2.14)\end{array}$ & $\begin{array}{l}0.09 * * \\
(2.04)\end{array}$ & $\begin{array}{l}0.09 * * \\
(2.09)\end{array}$ \\
\hline Senior & $\begin{array}{l}-1.60 * * * \\
(-2.94)\end{array}$ & $\begin{array}{l}-1.62 * * * \\
(-2.97)\end{array}$ & $\begin{array}{l}-1.61 * * * \\
(-2.94)\end{array}$ & $\begin{array}{l}-1.60 \text { *** } \\
(-2.89)\end{array}$ & $\begin{array}{l}-1.62 \text { *** } \\
(-2.93)\end{array}$ & $\begin{array}{l}-1.60 \text { *** } \\
(-2.90)\end{array}$ \\
\hline Secured & $\begin{array}{l}0.17 \text { ** } \\
(2.51)\end{array}$ & $\begin{array}{l}0.17 * * \\
(2.53)\end{array}$ & $\begin{array}{l}0.17 \text { ** } \\
(2.58)\end{array}$ & $\begin{array}{l}0.16 * * \\
(2.49)\end{array}$ & $\begin{array}{l}0.17 \text { ** } \\
(2.53)\end{array}$ & $\begin{array}{l}0.17 \text { ** } \\
(2.56)\end{array}$ \\
\hline Adjusted R-squared & 0.667 & 0.667 & 0.668 & 0.667 & 0.667 & 0.668 \\
\hline Observations & 1,600 & 1,600 & 1,600 & 1,600 & 1,600 & 1,600 \\
\hline
\end{tabular}


Table 4

$\underline{\text { Industry level analysis }}$

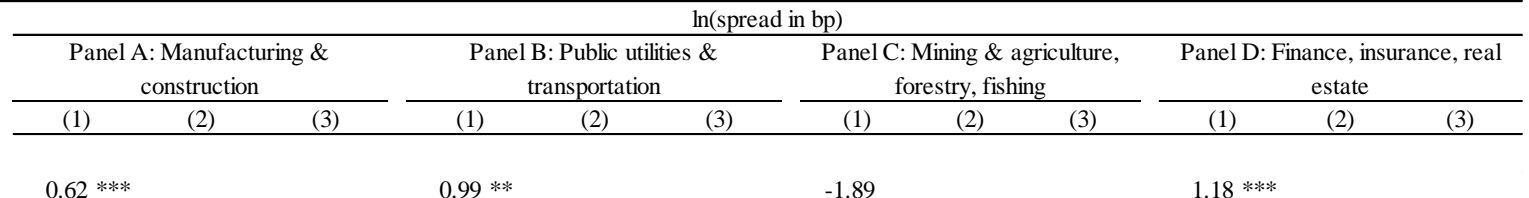

\begin{tabular}{|c|c|c|c|c|c|c|c|c|c|c|c|c|}
\hline \multicolumn{13}{|l|}{$\mathrm{CO}_{2}$ emissions } \\
\hline $\mathrm{CO}_{2}$ scope 1 & $\begin{array}{l}0.62 * * * \\
(3.37)\end{array}$ & & & $\begin{array}{l}0.99 \text { ** } \\
(2.12)\end{array}$ & & & $\begin{array}{r}-1.89 \\
(-0.69)\end{array}$ & & & $\begin{array}{l}1.18 \text { *** } \\
(5.24)\end{array}$ & & \\
\hline $\mathrm{CO}_{2}$ scope 2 & & $\begin{array}{r}1.20 \\
(1.41)\end{array}$ & & & $\begin{array}{c}0.61 * \\
(1.78)\end{array}$ & & & $\begin{array}{r}1.26 \\
(0.78)\end{array}$ & & & $\begin{array}{l}0.76 * * \\
(2.36)\end{array}$ & \\
\hline $\mathrm{CO}_{2}$ scope $1+2$ & & & $\begin{array}{l}0.54 * * * * \\
(3.31)\end{array}$ & & & $\begin{array}{l}0.81 \text { **** } \\
(3.16)\end{array}$ & & & $\begin{array}{r}0.33 \\
(0.23)\end{array}$ & & & $\begin{array}{l}0.76 \text { ***: } \\
(4.49)\end{array}$ \\
\hline Borrower characterist & & & & & & & & & & & & \\
\hline $\mathrm{ROA}$ & $\begin{array}{c}-0.89 * \\
(-1.92)\end{array}$ & $\begin{array}{c}-0.85 * \\
(-1.68)\end{array}$ & $\begin{array}{c}-0.90 * \\
(-1.92)\end{array}$ & $\begin{array}{l}-1.42 * * \\
(-2.06)\end{array}$ & $\begin{array}{l}-1.59 * * \\
(-2.25)\end{array}$ & $\begin{array}{l}-1.46 * * \\
(-2.11)\end{array}$ & $\begin{array}{r}-0.53 \\
(-1.63)\end{array}$ & $\begin{array}{c}-0.67 * \\
(-1.92)\end{array}$ & $\begin{array}{c}-0.66 * \\
(-1.99)\end{array}$ & $\begin{array}{r}-0.33 \\
(-0.29)\end{array}$ & $\begin{array}{r}0.09 \\
(0.07)\end{array}$ & $\begin{array}{r}-0.87 \\
(-0.81)\end{array}$ \\
\hline Leverage & $\begin{array}{r}-0.38 \\
(-1.56)\end{array}$ & $\begin{array}{r}-0.35 \\
(-1.42)\end{array}$ & $\begin{array}{r}-0.38 \\
(-1.57)\end{array}$ & $\begin{array}{r}-0.41 \\
(-1.60)\end{array}$ & $\begin{array}{l}-0.46 * \\
(-1.81)\end{array}$ & $\begin{array}{c}-0.45 * \\
(-1.78)\end{array}$ & $\begin{array}{r}0.69 \\
(1.21)\end{array}$ & $\begin{array}{r}0.61 \\
(1.19)\end{array}$ & $\begin{array}{r}0.56 \\
(1.05)\end{array}$ & $\begin{array}{l}0.52 \text { *** } \\
(2.71)\end{array}$ & $\begin{array}{r}0.26 \\
(1.12)\end{array}$ & $\begin{array}{r}0.24 \\
(1.40)\end{array}$ \\
\hline $\ln$ (Total assets) & $\begin{array}{r}-0.04 \\
(-1.13)\end{array}$ & $\begin{array}{r}-0.04 \\
(-1.20)\end{array}$ & $\begin{array}{r}-0.04 \\
(-1.11)\end{array}$ & $\begin{array}{l}-0.09 * \\
(-1.86)\end{array}$ & $\begin{array}{l}-0.11 \text { ** } \\
(-2.30)\end{array}$ & $\begin{array}{l}-0.09 * \\
(-1.95)\end{array}$ & $\begin{array}{r}-0.11 \\
(-1.20)\end{array}$ & $\begin{array}{r}-0.09 \\
(-0.93)\end{array}$ & $\begin{array}{r}-0.09 \\
(-1.01)\end{array}$ & $\begin{array}{r}-0.00 \\
(-0.04)\end{array}$ & $\begin{array}{r}-0.02 \\
(-0.49)\end{array}$ & $\begin{array}{r}-0.01 \\
(-0.17)\end{array}$ \\
\hline Loan characteristics & & & & & & & & & & & & \\
\hline Reputable arranger & $\begin{array}{c}-0.15 * \\
(-1.93)\end{array}$ & $\begin{array}{c}-0.15 * \\
(-1.92)\end{array}$ & $\begin{array}{c}-0.15 * \\
(-1.95)\end{array}$ & $\begin{array}{r}-0.12 \\
(-1.01)\end{array}$ & $\begin{array}{r}-0.12 \\
(-1.02)\end{array}$ & $\begin{array}{r}-0.11 \\
(-0.94)\end{array}$ & $\begin{array}{r}-0.12 \\
(-1.48)\end{array}$ & $\begin{array}{r}-0.10 \\
(-1.22)\end{array}$ & $\begin{array}{r}-0.10 \\
(-1.27)\end{array}$ & $\begin{array}{r}-0.21 \\
(-1.60)\end{array}$ & $\begin{array}{r}-0.18 \\
(-1.31)\end{array}$ & $\begin{array}{r}-0.18 \\
(-1.36)\end{array}$ \\
\hline $\ln ($ Loan size $)$ & $\begin{array}{r}-0.04 \\
(-1.12)\end{array}$ & $\begin{array}{r}-0.04 \\
(-1.07)\end{array}$ & $\begin{array}{r}-0.04 \\
(-1.13)\end{array}$ & $\begin{array}{r}0.05 \\
(1.13)\end{array}$ & $\begin{array}{r}0.05 \\
(1.24)\end{array}$ & $\begin{array}{r}0.05 \\
(1.16)\end{array}$ & $\begin{array}{l}0.10 * \\
(1.89)\end{array}$ & $\begin{array}{l}0.10 * \\
(1.92)\end{array}$ & $\begin{array}{l}0.10 * \\
(1.96)\end{array}$ & $\begin{array}{r}-0.03 \\
(-0.93)\end{array}$ & $\begin{array}{c}-0.07 * \\
(-1.82)\end{array}$ & $\begin{array}{r}-0.04 \\
(-1.24)\end{array}$ \\
\hline $\ln ($ Loan maturity) & $\begin{array}{r}-0.04 \\
(-1.34)\end{array}$ & $\begin{array}{r}-0.04 \\
(-1.34)\end{array}$ & $\begin{array}{r}-0.04 \\
(-1.29)\end{array}$ & $\begin{array}{r}0.02 \\
(0.29)\end{array}$ & $\begin{array}{r}0.01 \\
(0.16)\end{array}$ & $\begin{array}{r}0.02 \\
(0.27)\end{array}$ & $\begin{array}{r}-0.03 \\
(-0.44)\end{array}$ & $\begin{array}{r}-0.04 \\
(-0.48)\end{array}$ & $\begin{array}{r}-0.04 \\
(-0.50)\end{array}$ & $\begin{array}{r}0.06 \\
(1.44)\end{array}$ & $\begin{array}{r}0.07 \\
(1.46)\end{array}$ & $\begin{array}{r}0.06 \\
(1.32)\end{array}$ \\
\hline Multiple-tranche deal & $\begin{array}{c}0.11 \text { * } \\
(1.69)\end{array}$ & $\begin{array}{r}0.11 \\
(1.64)\end{array}$ & $\begin{array}{c}0.11 \text { * } \\
(1.68)\end{array}$ & $\begin{array}{r}0.06 \\
(1.02)\end{array}$ & $\begin{array}{r}0.04 \\
(0.75)\end{array}$ & $\begin{array}{r}0.04 \\
(0.74)\end{array}$ & $\begin{array}{l}0.17 \text { ** } \\
(2.14)\end{array}$ & $\begin{array}{c}0.18 * * \\
(2.25)\end{array}$ & $\begin{array}{l}0.17 \text { ** } \\
(2.19)\end{array}$ & $\begin{array}{r}0.04 \\
(0.56)\end{array}$ & $\begin{array}{r}0.10 \\
(1.16)\end{array}$ & $\begin{array}{r}0.07 \\
(1.00)\end{array}$ \\
\hline Performance pricing & $\begin{array}{r}0.02 \\
(0.25)\end{array}$ & $\begin{array}{r}0.03 \\
(0.44)\end{array}$ & $\begin{array}{r}0.02 \\
(0.25)\end{array}$ & $\begin{array}{l}0.28 \text { *** } \\
(3.35)\end{array}$ & $\begin{array}{l}0.29 * * * \\
(3.26)\end{array}$ & $\begin{array}{l}0.29 \text { *** } \\
(3.46)\end{array}$ & $\begin{array}{l}0.27 * \\
(1.90)\end{array}$ & $\begin{array}{l}0.27 * \\
(2.01)\end{array}$ & $\begin{array}{l}0.27 * \\
(1.94)\end{array}$ & $\begin{array}{r}-0.21 \\
(-1.23)\end{array}$ & $\begin{array}{r}0.15 \\
(0.93)\end{array}$ & $\begin{array}{r}-0.04 \\
(-0.25)\end{array}$ \\
\hline Financial covenants & $\begin{array}{r}-0.01 \\
(-0.14)\end{array}$ & $\begin{array}{r}-0.00 \\
(-0.06)\end{array}$ & $\begin{array}{r}-0.01 \\
(-0.12)\end{array}$ & $\begin{array}{r}0.10 \\
(0.94)\end{array}$ & $\begin{array}{r}0.11 \\
(1.07)\end{array}$ & $\begin{array}{r}0.10 \\
(1.00)\end{array}$ & $\begin{array}{r}0.10 \\
(1.11)\end{array}$ & $\begin{array}{r}0.11 \\
(1.16)\end{array}$ & $\begin{array}{r}0.11 \\
(1.14)\end{array}$ & $\begin{array}{c}-0.20 \text { * } \\
(-1.82)\end{array}$ & $\begin{array}{r}-0.06 \\
(-0.63)\end{array}$ & $\begin{array}{r}-0.13 \\
(-1.25)\end{array}$ \\
\hline Multiple base rates & $\begin{array}{r}0.13 \\
(1.62)\end{array}$ & $\begin{array}{r}0.11 \\
(1.47)\end{array}$ & $\begin{array}{r}0.12 \\
(1.58)\end{array}$ & $\begin{array}{c}-0.22 * \\
(-1.80)\end{array}$ & $\begin{array}{c}-0.24 * * \\
(-2.01)\end{array}$ & $\begin{array}{c}-0.22 * \\
(-1.87)\end{array}$ & $\begin{array}{r}-0.16 \\
(-1.02)\end{array}$ & $\begin{array}{r}-0.17 \\
(-1.06)\end{array}$ & $\begin{array}{r}-0.16 \\
(-1.02)\end{array}$ & $\begin{array}{r}0.22 \\
(1.40)\end{array}$ & $\begin{array}{c}-0.25 * \\
(-1.87)\end{array}$ & $\begin{array}{r}-0.03 \\
(-0.18)\end{array}$ \\
\hline Term loan & $\begin{array}{l}0.15 \text { ** } \\
(2.59)\end{array}$ & $\begin{array}{l}0.14 \text { ** } \\
(2.37)\end{array}$ & $\begin{array}{l}0.15 \text { ** } \\
(2.54)\end{array}$ & $\begin{array}{r}0.09 \\
(1.39)\end{array}$ & $\begin{array}{r}0.09 \\
(1.40)\end{array}$ & $\begin{array}{r}0.09 \\
(1.39)\end{array}$ & $\begin{array}{l}0.21 \\
(1.96)\end{array}$ & $\begin{array}{l}0.22 * * \\
(2.09)\end{array}$ & $\begin{array}{l}0.22 \text { ** } \\
(2.15)\end{array}$ & $\begin{array}{l}-0.29 \text { *** } \\
(-2.74)\end{array}$ & $\begin{array}{l}-0.24 * \\
(-1.96)\end{array}$ & $\begin{array}{c}-0.31 \text { ** } \\
(-2.66)\end{array}$ \\
\hline Senior & $\begin{array}{l}-2.67 * * * \\
(-5.76)\end{array}$ & $\begin{array}{l}-2.69 * * * \\
(-5.87)\end{array}$ & $\begin{array}{l}-2.67 * * * \\
(-5.78)\end{array}$ & & & & $\begin{array}{l}-0.55 * \\
(-2.01)\end{array}$ & $\begin{array}{l}-0.58 * * \\
(-2.30)\end{array}$ & $\begin{array}{l}-0.56 * * \\
(-2.17)\end{array}$ & & & \\
\hline Secured & $\begin{array}{r}0.06 \\
(0.60)\end{array}$ & $\begin{array}{r}0.05 \\
(0.57)\end{array}$ & $\begin{array}{r}0.05 \\
(0.56)\end{array}$ & $\begin{array}{l}0.30 \text { ** } \\
(2.04)\end{array}$ & $\begin{array}{l}0.31 \text { ** } \\
(2.06)\end{array}$ & $\begin{array}{l}0.31 \text { ** } \\
(2.10)\end{array}$ & $\begin{array}{r}0.19 \\
(1.06)\end{array}$ & $\begin{array}{r}0.19 \\
(1.17)\end{array}$ & $\begin{array}{r}0.19 \\
(1.10)\end{array}$ & $\begin{array}{l}0.25 \text { ** } \\
(2.64)\end{array}$ & $\begin{array}{c}0.18 * \\
(1.97)\end{array}$ & $\begin{array}{l}0.27 \text { ***: } \\
(3.36)\end{array}$ \\
\hline Adjusted R-squared & 0.724 & 0.721 & 0.724 & 0.689 & 0.687 & 0.690 & 0.792 & 0.792 & 0.790 & 0.813 & 0.793 & 0.813 \\
\hline Observations & 724 & 724 & 724 & 308 & 308 & 308 & 132 & 132 & 132 & 180 & 180 & 180 \\
\hline
\end{tabular}

Note: This table shows OLS regressions with heteroscedasticity robust standard errors clustered by borrower. For each independent variable, the top row shows the coefficient and the bottom row shows the t-statistic. All regressions include dummies for loan characteristics including loan purpose and year of loan signing as well as borrower characteristics including rating, industry and country. $* * * 1 \%, * * 5 \% * 10 \%$ significance. 
Table 5

Quantile analysis of $\mathrm{CO} 2$ emissions and the cost of debt

\begin{tabular}{|c|c|c|c|c|c|c|c|c|c|}
\hline & \multicolumn{9}{|c|}{$\ln ($ spread in bp $)$} \\
\hline & \multicolumn{3}{|c|}{ Panel A: $25 \%$ quantile } & \multicolumn{3}{|c|}{ Panel B: $50 \%$ quantile } & \multicolumn{3}{|c|}{ Panel C: $75 \%$ quantile } \\
\hline & $(1)$ & $(2)$ & (3) & (1) & (2) & (3) & $(1)$ & (2) & (3) \\
\hline \multicolumn{10}{|l|}{$\mathrm{CO}_{2}$ emissions } \\
\hline $\mathrm{CO}_{2}$ scope 1 & $\begin{array}{l}0.30 * * \\
(2.09)\end{array}$ & & & $\begin{array}{l}0.31 * * \\
(2.01)\end{array}$ & & & $\begin{array}{l}0.38 * * \\
(2.26)\end{array}$ & & \\
\hline $\mathrm{CO}_{2}$ scope 2 & & $\begin{array}{l}0.60 * * * \\
(4.23)\end{array}$ & & & $\begin{array}{l}0.46 \text { ** } \\
(2.43)\end{array}$ & & & $\begin{array}{l}0.50 \text { *** } \\
(2.59)\end{array}$ & \\
\hline $\mathrm{CO}_{2}$ scope $1+2$ & & & $\begin{array}{l}0.33 \text { *** } \\
(3.52)\end{array}$ & & & $\begin{array}{l}0.33 \text { *** } \\
(2.97)\end{array}$ & & & $\begin{array}{l}0.36 \text { *** } \\
(3.85)\end{array}$ \\
\hline \multicolumn{10}{|l|}{ Borrower characteristics } \\
\hline ROA & $\begin{array}{l}-1.10 * * * \\
(-4.80)\end{array}$ & $\begin{array}{l}-0.99 * * * \\
(-4.71)\end{array}$ & $\begin{array}{l}-0.98 \text { *** } \\
(-4.16)\end{array}$ & $\begin{array}{l}-0.78 \text { *** } \\
(-4.91)\end{array}$ & $\begin{array}{l}-0.81 \text { *** } \\
(-6.14)\end{array}$ & $\begin{array}{l}-0.83 \text { *** } \\
(-5.17)\end{array}$ & $\begin{array}{l}-0.49 * * \\
(-2.56)\end{array}$ & $\begin{array}{l}-0.52 * * * \\
(-3.06)\end{array}$ & $\begin{array}{l}-0.55 \text { *** } \\
(-3.06)\end{array}$ \\
\hline Leverage & $\begin{array}{r}0.01 \\
(0.13)\end{array}$ & $\begin{array}{r}0.05 \\
-0.48\end{array}$ & $\begin{array}{r}0.04 \\
-0.33\end{array}$ & $\begin{array}{r}0.09 \\
(0.83)\end{array}$ & $\begin{array}{r}0.04 \\
(0.29)\end{array}$ & $\begin{array}{r}-0.02 \\
(-0.13)\end{array}$ & $\begin{array}{r}0.07 \\
(0.56)\end{array}$ & $\begin{array}{r}0.06 \\
-0.47\end{array}$ & $\begin{array}{r}0.02 \\
-0.19\end{array}$ \\
\hline $\ln$ (Total assets) & $\begin{array}{l}-0.09 * * * \\
(-4.84)\end{array}$ & $\begin{array}{l}-0.10 \text { *** } \\
(-5.43)\end{array}$ & $\begin{array}{l}-0.09 \text { *** } \\
(-4.94)\end{array}$ & $\begin{array}{l}-0.08 \text { *** } \\
(-5.24)\end{array}$ & $\begin{array}{l}-0.08 * * * \\
(-5.06)\end{array}$ & $\begin{array}{l}-0.08 \text { *** } \\
(-4.81)\end{array}$ & $\begin{array}{l}-0.07 * * * \\
(-3.72)\end{array}$ & $\begin{array}{l}-0.08 \text { *** } \\
(-4.05)\end{array}$ & $\begin{array}{l}-0.07 \text { *** } \\
(-3.33)\end{array}$ \\
\hline \multicolumn{10}{|l|}{ Loan characteristics } \\
\hline Reputable arranger & $\begin{array}{r}-0.03 \\
(-0.71)\end{array}$ & $\begin{array}{r}-0.06 \\
(-1.35)\end{array}$ & $\begin{array}{r}-0.04 \\
(-0.88)\end{array}$ & $\begin{array}{c}-0.08 * \\
(-1.96)\end{array}$ & $\begin{array}{l}-0.09 * \\
(-1.93)\end{array}$ & $\begin{array}{l}-0.09 \text { ** } \\
(-2.08)\end{array}$ & $\begin{array}{l}-0.13 \text { *** } \\
(-2.59)\end{array}$ & $\begin{array}{l}-0.12 \text { ** } \\
(-2.22)\end{array}$ & $\begin{array}{l}-0.14 \text { ** } \\
(-2.48)\end{array}$ \\
\hline $\ln ($ Loan size $)$ & $\begin{array}{r}0.00 \\
(0.25)\end{array}$ & $\begin{array}{r}0.00 \\
(-0.00)\end{array}$ & $\begin{array}{r}0.00 \\
(-0.00)\end{array}$ & $\begin{array}{r}0.00 \\
(0.25)\end{array}$ & $\begin{array}{r}-0.00 \\
(-0.00)\end{array}$ & $\begin{array}{r}0.00 \\
(-0.00)\end{array}$ & $\begin{array}{r}-0.01 \\
(-0.76)\end{array}$ & $\begin{array}{r}-0.01 \\
(-0.89)\end{array}$ & $\begin{array}{r}-0.02 \\
(-1.08)\end{array}$ \\
\hline $\ln$ (Loan maturity) & $\begin{array}{r}0.00 \\
(0.04)\end{array}$ & $\begin{array}{l}0.00 \\
0.00\end{array}$ & $\begin{array}{r}0.00 \\
(-0.07)\end{array}$ & $\begin{array}{r}-0.02 \\
(-0.81)\end{array}$ & $\begin{array}{r}-0.03 \\
(-1.03)\end{array}$ & $\begin{array}{r}-0.02 \\
(-0.71)\end{array}$ & $\begin{array}{l}-0.06 * * \\
(-2.23)\end{array}$ & $\begin{array}{l}-0.05 * \\
(-1.76)\end{array}$ & $\begin{array}{l}-0.06 \text { ** } \\
(-2.23)\end{array}$ \\
\hline Multiple-tranche deal & $\begin{array}{r}0.04 \\
(1.30)\end{array}$ & $\begin{array}{l}0.07 * * \\
-1.97\end{array}$ & $\begin{array}{r}0.05 \\
-1.58\end{array}$ & $\begin{array}{r}0.05 \\
(1.61)\end{array}$ & $\begin{array}{r}0.05 \\
(1.55)\end{array}$ & $\begin{array}{c}0.05 * \\
-1.67\end{array}$ & $\begin{array}{r}0.06 \\
(1.41)\end{array}$ & $\begin{array}{r}0.05 \\
-1.16\end{array}$ & $\begin{array}{r}0.06 \\
-1.50\end{array}$ \\
\hline Performance pricing & $\begin{array}{r}0.04 \\
(1.01)\end{array}$ & $\begin{array}{r}0.03 \\
-0.73\end{array}$ & $\begin{array}{r}0.01 \\
-0.33\end{array}$ & $\begin{array}{r}0.05 \\
(1.12)\end{array}$ & $\begin{array}{r}0.04 \\
(0.90)\end{array}$ & $\begin{array}{r}0.04 \\
-1.10\end{array}$ & $\begin{array}{r}0.05 \\
(1.29)\end{array}$ & $\begin{array}{l}0.07 * \\
-1.73\end{array}$ & $\begin{array}{r}0.05 \\
-1.18\end{array}$ \\
\hline Financial covenants & $\begin{array}{c}0.06 * \\
(1.65)\end{array}$ & $\begin{array}{l}0.07 * \\
-1.71\end{array}$ & $\begin{array}{l}0.06 * \\
-1.68\end{array}$ & $\begin{array}{l}0.07 \text { ** } \\
(1.96)\end{array}$ & $\begin{array}{l}0.07 * * \\
(2.27)\end{array}$ & $\begin{array}{c}0.06 * \\
-1.66\end{array}$ & $\begin{array}{r}0.00 \\
(0.09)\end{array}$ & $\begin{array}{r}0.00 \\
(-0.04)\end{array}$ & $\begin{array}{r}0.01 \\
-0.29\end{array}$ \\
\hline Multiple base rates & $\begin{array}{r}0.00 \\
(0.07)\end{array}$ & $\begin{array}{r}-0.02 \\
(-0.42)\end{array}$ & $\begin{array}{r}0.02 \\
-0.30\end{array}$ & $\begin{array}{r}-0.01 \\
(-0.29)\end{array}$ & $\begin{array}{r}-0.02 \\
(-0.47)\end{array}$ & $\begin{array}{r}0.00 \\
(-0.09)\end{array}$ & $\begin{array}{r}0.06 \\
(1.16)\end{array}$ & $\begin{array}{r}0.03 \\
-0.63\end{array}$ & $\begin{array}{r}0.05 \\
-0.99\end{array}$ \\
\hline Term loan & $\begin{array}{l}0.08 \text { ** } \\
(2.15)\end{array}$ & $\begin{array}{l}0.09 * * \\
-2.54\end{array}$ & $\begin{array}{l}0.09 * * \\
-2.26\end{array}$ & $\begin{array}{l}0.09 * * \\
(2.46)\end{array}$ & $\begin{array}{l}0.09 \text { ** } \\
(2.56)\end{array}$ & $\begin{array}{l}0.09 \text { *** } \\
-2.64\end{array}$ & $\begin{array}{l}0.12 \text { *** } \\
(3.02)\end{array}$ & $\begin{array}{l}0.09 * * \\
-1.99\end{array}$ & $\begin{array}{l}0.12 * * * \\
-3.17\end{array}$ \\
\hline Senior & $\begin{array}{r}-0.69 \\
(-0.63)\end{array}$ & $\begin{array}{r}-1.22 \\
(-1.27)\end{array}$ & $\begin{array}{r}-0.71 \\
(-0.63)\end{array}$ & $\begin{array}{l}-2.65 * * * \\
(-2.71)\end{array}$ & $\begin{array}{l}-2.63 * * * \\
(-2.66)\end{array}$ & $\begin{array}{l}-2.60 * * * \\
(-2.61)\end{array}$ & $\begin{array}{l}-2.05 * * * \\
(-3.12)\end{array}$ & $\begin{array}{l}-2.03 \text { *** } \\
(-2.79)\end{array}$ & $\begin{array}{l}-2.03 \text { *** } \\
(-2.87)\end{array}$ \\
\hline Secured & $\begin{array}{l}0.12 \text { ** } \\
(2.11)\end{array}$ & $\begin{array}{r}0.09 \\
-1.40\end{array}$ & $\begin{array}{l}0.11 * \\
-1.82\end{array}$ & $\begin{array}{l}0.14 \text { **** } \\
(2.64)\end{array}$ & $\begin{array}{l}0.13 * * \\
(2.50)\end{array}$ & $\begin{array}{l}0.15 * * * \\
-2.89\end{array}$ & $\begin{array}{l}0.15 \text { *** } \\
(2.98)\end{array}$ & $\begin{array}{l}0.14 \text { *** } \\
-3.00\end{array}$ & $\begin{array}{l}0.15 * * * \\
-3.01\end{array}$ \\
\hline Pseudo R-squared & 0.545 & 0.546 & 0.546 & 0.481 & 0.481 & 0.482 & 0.438 & 0.438 & 0.439 \\
\hline Observations & 1,600 & 1,600 & 1,600 & 1,600 & 1,600 & 1,600 & 1,600 & 1,600 & 1,600 \\
\hline
\end{tabular}


Table 6

Borrower's control over emissions

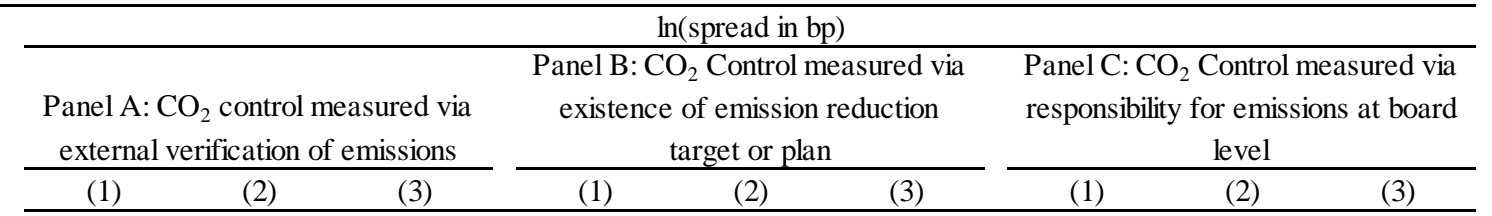

$\mathrm{CO}_{2}$ emissions

\begin{tabular}{|c|c|c|c|}
\hline $\mathrm{CO}_{2}$ scope $1 * \mathrm{CO}_{2}$ control $_{\text {strong }}$ & $\begin{array}{r}0.18 \\
(1.17)\end{array}$ & & \\
\hline $\mathrm{CO}_{2}$ scope $1 * \mathrm{CO}_{2}$ control ${ }_{\text {weak }}$ & $\begin{array}{l}0.71 \text { *** } \\
(2.69)\end{array}$ & & \\
\hline $\mathrm{CO}_{2}$ scope $2 * \mathrm{CO}_{2}$ control $_{\text {strong }}$ & & $\begin{array}{r}0.39 \\
(1.41)\end{array}$ & \\
\hline $\mathrm{CO}_{2}$ scope $2 * \mathrm{CO}_{2}$ control $_{\text {weak }}$ & & $\begin{array}{l}0.79 \text { *** } \\
(4.09)\end{array}$ & \\
\hline $\mathrm{CO}_{2}$ scope $1+2 * \mathrm{CO}_{2}$ control $_{\text {strong }}$ & & & $\begin{array}{r}0.16 \\
(1.21)\end{array}$ \\
\hline $\mathrm{CO}_{2}$ scope $1+2 * \mathrm{CO}_{2}$ control $_{\text {weak }}$ & & & $\begin{array}{l}0.50 \text { *** } \\
(4.05)\end{array}$ \\
\hline
\end{tabular}

$0.37 * *$

(2.32)

0.65

(1.29) (3)

(1)

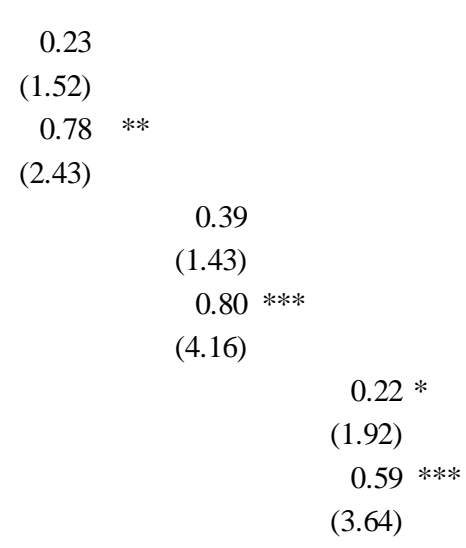

Borrower characteristics

Loan characteristics

$\begin{array}{rrrrrrrrr}\text { yes } & \text { yes } & \text { yes } & \begin{array}{r}\text { yes } \\ \text { yes }\end{array} & \begin{array}{r}\text { yes } \\ \text { yes }\end{array} & \begin{array}{r}\text { yes } \\ \text { yes }\end{array} & \begin{array}{r}\text { yes } \\ \text { yes }\end{array} & \begin{array}{r}\text { yes } \\ \text { yes }\end{array} & \begin{array}{r}\text { yes } \\ \text { yes }\end{array} \\ 0.668 & 0.667 & 0.669 & 0.667 & 0.667 & 0.668 & 0.668 & 0.667 & 0.669 \\ 1,600 & 1,600 & 1,600 & 1,600 & 1,600 & 1,600 & 1,600 & 1,600 & 1,600\end{array}$

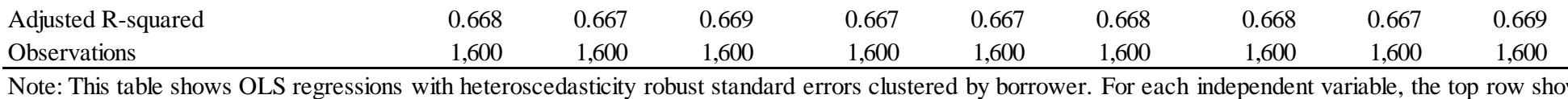

Note: This table shows OLS regressions with heteroscedasticity robust standard errors clustered by borrower. For each independent variable, the top row shows the coefficient and the bottom row shows the t-statistic. All regressions include dummies for loan characteristics including loan purpose and year of loan signing as well as borrower characteristics including rating, industry and country. $* * * 1 \%, * * 5 \%, * 10 \%$ significance. 